\title{
Hydrologic Investigation of the Ophir Creek Watershed Near Yakutat, Alaska
}

by Edward G. Neal

U.S. GEOLOGICAL SURVEY

Open-File Report 98-199

Prepared in cooperation with the

Alaska Department of Fish and Game 


\section{U.S. DEPARTMENT OF THE INTERIOR \\ BRUCE BABBITT, Secretary}

\section{U.S. GEOLOGICAL SURVEY}

Thomas J. Casadevall, Acting Director

Use of trade names in this report is for identification purposes only and does not constitute endorsement by the U.S. Geological Survey.

For additional information:

District Chief U.S. Geological Survey 4230 University Drive, Suite 201 Anchorage, AK 99508-4664

http://www-water-ak.usgs.gov
Copies of this report may be purchased from:

U.S. Geological Survey Branch of Information Services Box 25286

Denver, CO 80225-0286 


\section{CONTENTS}

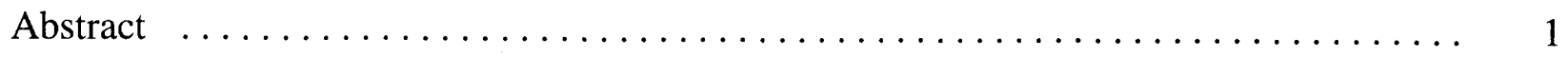

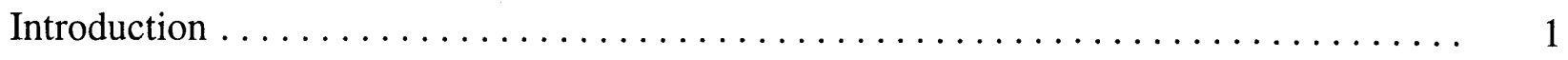

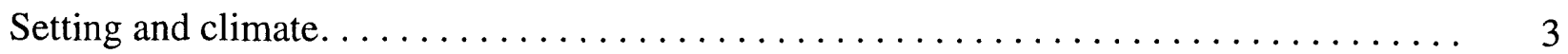

Description of Ophir Creek watershed $\ldots \ldots \ldots \ldots \ldots \ldots \ldots \ldots \ldots \ldots \ldots \ldots \ldots$

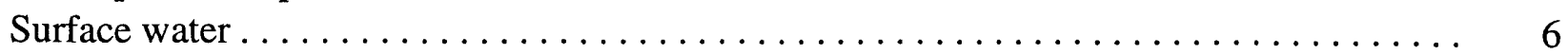

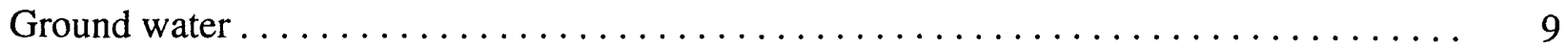

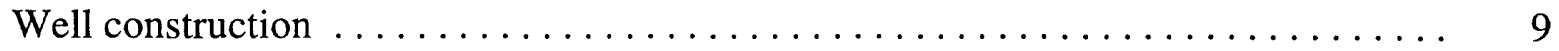

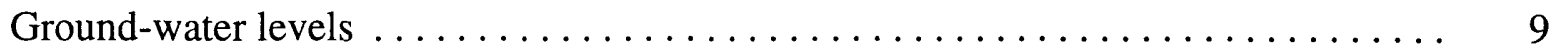

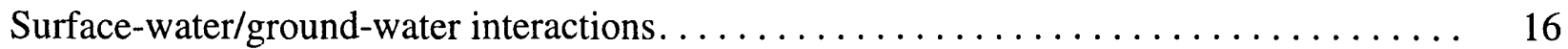

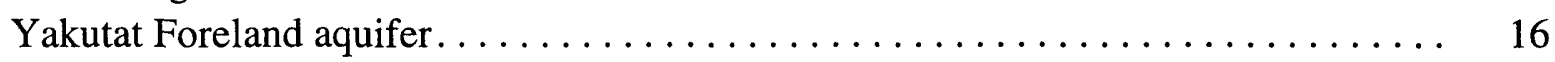

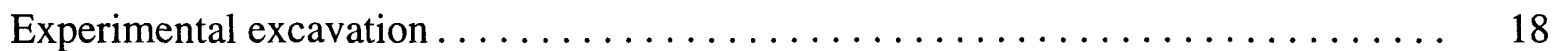

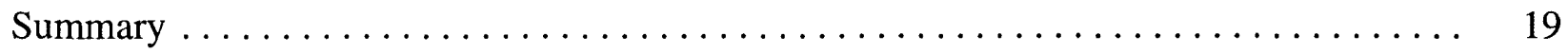

References cited................................ 20

Appendix 1: Drilling logs of monitoring wells $1-7 \ldots \ldots \ldots \ldots \ldots \ldots \ldots \ldots \ldots \ldots$

Appendix 2: Water-level measurements from monitoring wells 1-7, October 1996

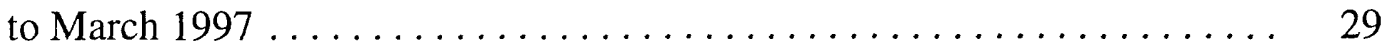

\section{FIGURES}

1-2. Maps showing:

1. Location of Yakutat, Alaska, and Ophir Creek ............... 2

2. Location of surface- and ground-water data-collection sites, Ophir

Creek watershed .

3-4. Hydrographs showing:

3. Daily mean discharge of Ophir Creek near Yakutat, July 1995 through

September 1996, and mean monthly discharge . . . . . . . . . . . .

4. Water levels, July 1995 through September 1996:
A. Well 1
B. Well 2 .
C. Well 3 .
D. Well 4
E. Well 5
F. Well 6
G. Well 7 .

5. Graph showing daily precipitation at Yakutat Airport, July 1995 through

September 1996

6-8. Sketches showing generalized ground-water flow in a homogeneous water-table aquifer:

6. Having two streams and numerous streams $\ldots \ldots \ldots \ldots \ldots \ldots \ldots \ldots \ldots$

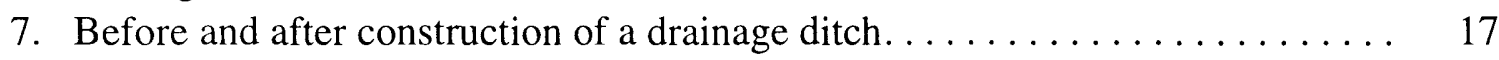

8. Before and after excavation of an existing stream channel $\ldots \ldots \ldots \ldots \ldots$ 


\section{TABLES}

1. Mean monthly temperature, precipitation, and snowfall for the period 1948 to 1987, Yakutat, Alaska. . . . . . . . . . . . . . . . . . . . . . . . . . . . .

2. Stream-discharge measurement sites in the Ophir Creek watershed near Yakutat, Alaska, 1992-97 water years . . . . . . . . . . . . . . . . . . . . 6

3. Stream-discharge measurements at six sites in the Ophir Creek watershed, Alaska, and gains in stream discharge between sites, 1992-97 . . . . . . . . . . 8

4. Information about monitoring wells in the Ophir Creek watershed, Alaska ...... 10

\section{CONVERSION FACTORS AND VERTICAL DATUM}

\begin{tabular}{rll}
\hline Multiply & by & To obtain \\
\hline inch & 25.4 & millimeter \\
foot & 0.3048 & meter \\
mile & 1.609 & kilometer \\
square mile & 2.590 & square kilometer \\
cubic foot per second & 0.02832 & cubic meter per second \\
gallon per minute & 0.06309 & liter per second \\
\hline
\end{tabular}

Temperature in degrees Fahrenheit $\left({ }^{\circ} \mathrm{F}\right)$ may be converted to degrees Celsius $\left({ }^{\circ} \mathrm{C}\right)$ as follows:

$$
{ }^{\circ} \mathrm{C}=\left({ }^{\circ} \mathrm{F}-32\right) / 1.8
$$

\section{VERTICAL DATUM:}

Sea level: In this report, "sea level" refers to the National Geodetic Vertical Datum of 1929-A geodetic datum derived from a general adjustment of the first-order level nets of the United States and Canada, formerly called Sea Level Datum of 1929. 


\title{
Hydrologic Investigation of the Ophir Creek Watershed Near Yakutat, Alaska
}

\author{
by Edward G. Neal
}

\begin{abstract}
Data on streamflow and ground-water levels were collected in the Ophir Creek watershed in southeast Alaska to obtain information about the relations between streamflow, ground-water levels, and precipitation. In addition, the possible effect of an experimental channel excavation to increase flows in Ophir Creek was evaluated. Stream discharges were monitored continuously at one site and measured intermittently at five other sites from October 1991 to May 1997, and ground-water levels were measured weekly in seven wells from July 1995 to October 1996. All measured ground-water levels were less than 11.4 feet below land surface. The data indicate that ground-water levels are closely related to rain and snowmelt, which in turn are related to water levels in Ophir Creek. Six of seven wells had peak water levels concurrent with peak flows in Ophir Creek. In one well, both maximum and minimum water levels coincided with maximum and minimum streamflow in Ophir Creek. Deepening part of the Ophir Creek channel by excavation has increased streamflows along the deepened reach; however, some of this additional flow infiltrates into the stream channel downstream from the excavated reach. The deepened reach flowed intermittently before the excavation and continues to dewater during prolonged periods of no precipitation.
\end{abstract}

\section{INTRODUCTION}

Ophir Creek, near the community of Yakutat (population approximately 800) in southeastern Alaska (fig. 1), has historically been important to the subsistence lifestyle of Yakutat residents because of its abundant production of sockeye and coho salmon. Historical data on subsistence harvest are not available, and adult salmon escapement surveys prior to 1994 are limited. Adult salmon escapement surveys done since 1994 indicate that as many as 5,000 to 6,000 adult coho salmon and 5,000 to 7,000 adult sockeye salmon spawn in Ophir Creek (Susan Walker, U.S. Fish and Wildlife Service, oral commun., 1997).

In recent years, local residents have been increasingly concerned that development activities-such as logging, road building, and urbanization-may be responsible for an apparent diminished base flow in the creek. During June, July, August, and extended cold periods in some winter months, much of the Ophir Creek channel in the upper watershed can become dry, resulting in mass mortality of salmon eggs and juveniles in these reaches. The Alaska Department of Fish and Game, the U.S. Fish and Wildlife Service, the U.S. Forest Service, and the City and Borough of Yakutat Salmon Enhancement Board have been working to improve the aquatic habitat for salmon in the Ophir Creek watershed. 


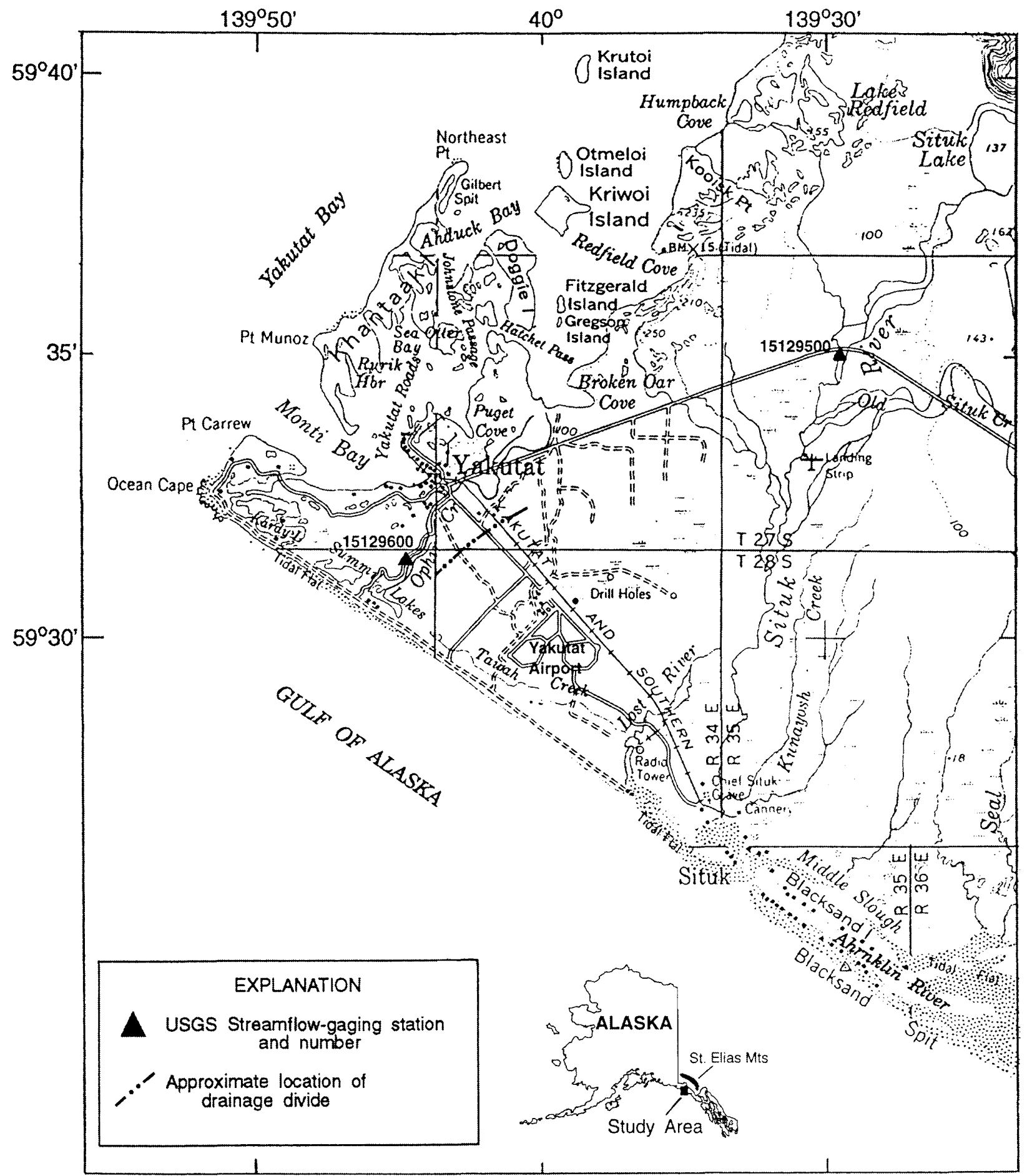

Base from U.S. Geological Survey, Yakutat, Alaska-Canada, 1:250,000, 1959

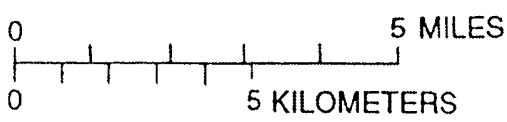

CONTOUR INTERVAL 200 FEET

NATIONAL GEODETIC VERTICAL DATUM OF 1929

Figure 1. Location of Yakutat, Alaska and Ophir Creek. 
No streamflow records of Ophir Creek exist before October 1991; however, a report by Bishop (1986) suggests that Ophir Creek (in addition to other streams in the region) may have sustained greater surface-water discharges in the early part of the $20^{\text {th }}$ century. Although no data are available to support this suggestion, there are indirect indicators. These include (1) the outsized channel the stream occupies, (2) the recent encroachment of riparian vegetation along the stream channel, and (3) the testimony from several Yakutat residents that the stream formerly was navigable by canoe up to the current culvert at the road to the airport (site B, fig. 2). Bishop (1986) further indicates that the upper reaches of Ophir Creek first began dewatering in 1968. Bishop's work included cumulative curves developed for total precipitation and July rainfall from 1931 to 1984. He concluded that a reduction in Yakutat precipitation had not occurred and was not a causal factor in reduction of Ophir Creek streamflows.

In 1995, the U.S. Geological Survey (USGS), in cooperation with the Alaska Department of Fish and Game, began a study in the Ophir Creek watershed to determine relations between ground-water levels, precipitation, and streamflow. Seven wells were installed in and around the watershed to monitor ground-water levels.

This report presents and summarizes data on ground-water levels from the seven monitoring wells, streamflow data from the USGS gaging station designated as "Ophir Creek near Yakutat," and miscellaneous streamflow data from five other sites in the Ophir Creek watershed. In addition, the report describes general aquifer characteristics, spatial and temporal variations in ground-water levels, and possible effects of an experimental excavation completed in an attempt to induce perennial flows in previously intermittent reaches of Ophir Creek.

\section{SETTING AND CLIMATE}

The Yakutat area, commonly called the "Yakutat Foreland," is a lowland bounded on the south by the Gulf of Alaska and on the north and east by the St. Elias Mountains (Wahrhaftig, 1965). These mountains are a continuation of the Pacific Mountain System of the western United States and Canada. The elevation of the Yakutat Foreland ranges from sea level to about 3,900 feet. Most of the area slopes gently toward the south, except near the coastline of Yakutat Bay, which consists of steep bluffs exposing glacial moraine deposits formed during the retreat of the Yakutat Bay Glacier about 500 years ago (Holmes and Dorava, 1995, p. 4).

The climate of the Yakutat Foreland area is characterized by mild temperatures and small temperature variations, high humidity, heavy precipitation, cloudy skies, and fog (Hartman and Johnson, 1984). Precipitation and temperature data collected at the Yakutat Airport (table 1) show that the mean annual temperature is about $39^{\circ} \mathrm{F}$, the mean minimum January temperature is about $19^{\circ} \mathrm{F}$, and the mean maximum August temperature is about $60^{\circ} \mathrm{F}$. Mean annual precipitation is about 151 inches, and, on the average, 182 days per year have more than 0.10 inch of precipitation (National Oceanic and Atmospheric Administration, 194696). The Yakutat Airport has a mean annual snowfall of almost 18 feet (Leslie, 1989). 


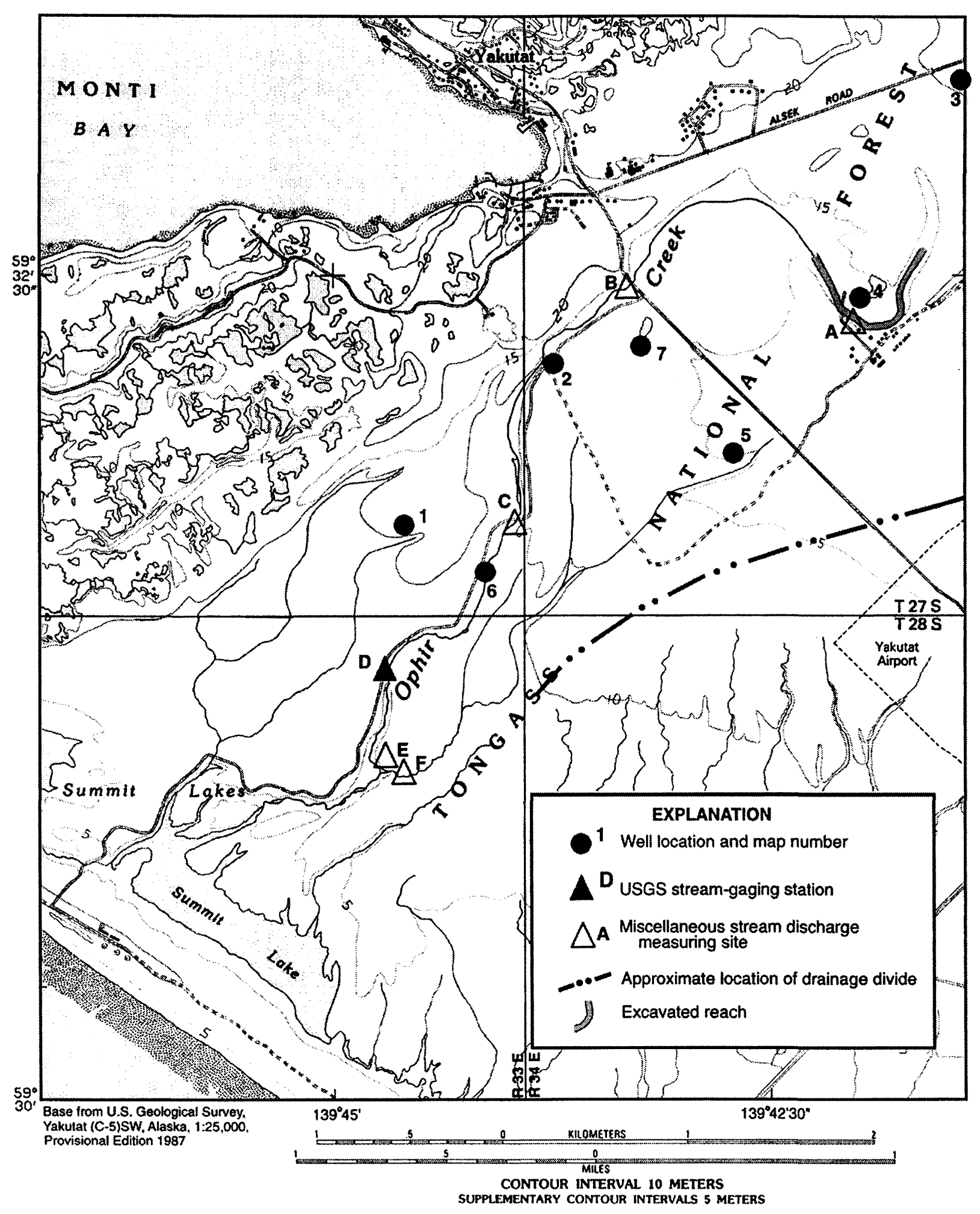

Figure 2. Location of surface-water and ground-water data-collection sites, Ophir Creek watershed. 
Table 1. Mean monthly temperature, precipitation, and snowfall for the period 1948 to 1987 , and total monthly and annual precipitation for 1992 through 1996,Yakutat, Alaska

[Temperature and precipitation data from the National Oceanic and Atmospheric Administration; snowfall data from Leslie, 1989]

Jan. Feb. Mar. April May June July Aug. Sept. Oct. Nov. Dec. Annual

Temperature (degrees Fahrenheit)

$\begin{array}{cccccccccccccc}\text { Mean maximum } & 31.5 & 35.0 & 38.2 & 43.5 & 50.0 & 55.6 & 59.3 & 59.8 & 55.3 & 47.1 & 37.3 & 33.1 & 45.5 \\ \text { Mean minimum } & 18.6 & 21.1 & 28.7 & 29.1 & 36.5 & 43.3 & 47.8 & 46.5 & 41.0 & 34.7 & 25.2 & 21.1 & 32.4 \\ \text { Mean } & 25.1 & 28.0 & 31.0 & 36.3 & 43.3 & 49.4 & 53.6 & 53.2 & 48.2 & 40.9 & 31.3 & 27.1 & 39.0\end{array}$

Precipitation (water equivalent, in inches)

$\begin{array}{lccccccccccccc}\text { Mean } & 12.2 & 10.7 & 10.7 & 9.9 & 9.7 & 7.3 & 8.2 & 11.5 & 18.7 & 23 & 14.5 & 14.9 & 151.3 \\ 1992 & 29.8 & 19.5 & 37.3 & 5.5 & 12.9 & 13.6 & 7.8 & 20.8 & 16.9 & 27.1 & 28.1 & 12.9 & 232.3 \\ 1993 & 10.6 & 11.3 & 6.0 & 6.2 & 4.8 & 3.0 & 2.5 & 12.1 & 22.7 & 23.2 & 16.1 & 19.7 & 138.2 \\ 1994 & 8.8 & 1.4 & 24.2 & 9.5 & 14.5 & 5.8 & 9.1 & 5.6 & 21.8 & 33.2 & 13.3 & 15.6 & 162.8 \\ 1995 & 9.6 & 11.6 & 6.6 & 10.8 & 10.2 & 9.6 & 6.1 & 10.7 & 27.8 & 17.2 & 9.1 & 9.7 & 139.0 \\ 1996 & 2.4 & 13.7 & 12.8 & 7.9 & 3.2 & 10.7 & 3.1 & 23.3 & 17.2 & 13.6 & 7.8 & 9.1 & 124.8\end{array}$

Snowfall (inches)

$\begin{array}{llllllllllllll}\text { Mean } & 39.9 & 40.5 & 42.2 & 18.4 & 1.8 & 0 & 0 & 0 & \text { Trace } & 5.8 & 22.3 & 43.3 & 214.2\end{array}$

\section{DESCRIPTION OF OPHIR CREEK WATERSHED}

The Ophir Creek watershed (figs. 1 and 2) occupies about 4 square miles of the Yakutat Foreland. The watershed's northwest headwaters are relics of glacial moraines that extend along Monti Bay to Redfield Cove (fig. 1). This morainal area consists of hummocky terrain pocketed with small lakes. The moraine deposits on the northwest edge of the Ophir Creek watershed vary in thickness up to about 250 feet and are made up of granule- and pebblerich silt and sand, with some cobbles, clay, and boulders (Holmes and Dorava, 1995, p. 8).

The middle and lower parts of the watershed, which contain the perennial reaches of Ophir Creek, have little topographic relief: elevations range from about 10 to 55 feet above sea level. Channel surveys conducted by
Alaska Department of Fish and Game (written commun., 1995) from sites B to $E$ (fig. 2) indicate a stream gradient of about 0.0021 . Exposed sediments in this region are chiefly sand and gravel deposited by glacial meltwater streams. These outwash deposits range in thickness from about 3 to 56 feet (Holmes and Dorava, 1995, p. 5). The coarse-grained deposits begin close to the end moraines near Yakutat Bay. The grain size of the deposits decreases farther downstream and southward of the end moraines.

Topographic maps and aerial photographs of the area indicate that channels are large in relation to current streamflows in Ophir Creek. These oversized channels were formed by meltwater streams that were larger than the present Ophir Creek. The width of the currently active stream channel typically ranges from about 20 to 40 feet in the reach between sites B 
and E (fig. 2). Ophir Creek streamflow appears to be sustained primarily from rain and snowmelt percolating into outwash deposits, moving laterally as ground water, and then discharging into the stream channel. Ophir Creek terminates at Summit Lake where it discharges to Tawah Creek (fig. 1). Unlike most other streams in the Yakutat Foreland, which flow in a north-to-southwest direction, Tawah Creek flows to the southeast. This southeastward flow is caused by beach deposits that form a topographic barrier along the Gulf of Alaska. Tawah Creek, which collects tributary flow from numerous small streams and man-made drains originating within the area, discharges to the Lost River near its confluence with the Gulf of Alaska (Holmes and Dorava, 1995, p. 8).

\section{SURFACE WATER}

Stream discharge data have been collected continuously at USGS stream-gaging station, Ophir Creek near Yakutat (No. 15129600, fig. 1; site D, fig. 2) since October 1991. Discharge data were collected intermittently at five sites in the Ophir Creek watershed (fig. 2 and table 2) from April 1992 until May 1997.
Ophir Creek at the stream-gaging station (site D), drains an area of approximately 2.5 square miles and had a mean annual discharge of 14.6 cubic feet per second for water years 1992-96 (U.S. Geological Survey, 1993-97). Highest flows typically occur in September, October, or November in response to rainfall. However, the highest flow recorded at the Ophir Creek gaging station was 88 cubic feet per second on March 10, 1992 and occurred when more than 16 inches of rain fell upon 16 inches of snow in a 4-day period beginning on March 7, 1992 (National Oceanic and Atmospheric Administration, 1992). The minimum discharge recorded at the Ophir Creek gaging station was 0.21 cubic foot per second during several days in July and August 1993. Because the stage could not be accurately recorded at these low flows, discharges are approximate.

Ground-water levels were monitored concurrently with streamflow from July 1995 to October 1996. During this period, the highest instantaneous discharge recorded was 66 cubic feet per second on September 22, 1995. The lowest instantaneous discharge was 1.3 cubic feet per second during early August 1996 (fig. 3). During the 1996 water year (October 1995

Table 2. Steam-discharge measurement sites in the Ophir Creek watershed near Yakutat, Alaska, 1992-97 water years

\begin{tabular}{ccl}
\hline $\begin{array}{c}\text { Site } \\
\text { (fig. 2) }\end{array}$ & USGS station No. & \multicolumn{1}{c}{ Station name } \\
\hline A & 15129585 & Ophir Creek at gravel pit road near Yakutat \\
B & 15129590 & Ophir Creek at Airport Road at Yakutat \\
C & 15129595 & Ophir Creek at Mile 1.0 near Yakutat \\
D & 15129600 & Ophir Creek near Yakutat (stream-gaging station) \\
E & 15129605 & Ophir Creek above tributary near Yakutat \\
F & 15129615 & Ophir Creek tributary at confluence near Yakutat \\
\hline
\end{tabular}


through September 1996), the annual mean discharge was 11.2 cubic feet per second, 77 percent of the 5-year mean. When the upper reaches of the watershed had no surface-water flow (intermittently from March through August), the mean monthly discharge at the Ophir Creek gaging station ranged from a low of 60 percent of the monthly mean for June to 100 percent of the monthly mean for August. Monthly mean discharge in May 1996 (6.2 cubic feet per second) was the lowest flow for May in the 5 years of record (62 percent of the monthly mean).

Stream discharges were measured intermittently at several sites on Ophir Creek to determine gains or losses in streamflow along its length (table 3). Observations of the Ophir Creek channel at sites A and B (fig. 2) show that it commonly has no flow and may completely dewater during the months of June, July, and August (table 3). Measurements also indicated that Ophir Creek gains significant quantities of water between site $B$ and site $C$ (approximately 1 river mile). The data show that when discharges at the Ophir Creek gaging station (site D) were more than 9.0 cubic feet per second, site C (approximately 0.8 river mile upstream from the gaging station) has about 70 to 95 percent of the flow recorded at the station. When discharges at the Ophir Creek gaging station were less than 5.4 cubic feet per second, discharges at site $\mathrm{C}$ were about 20 to 60 percent less than discharges at site $\mathrm{D}$.

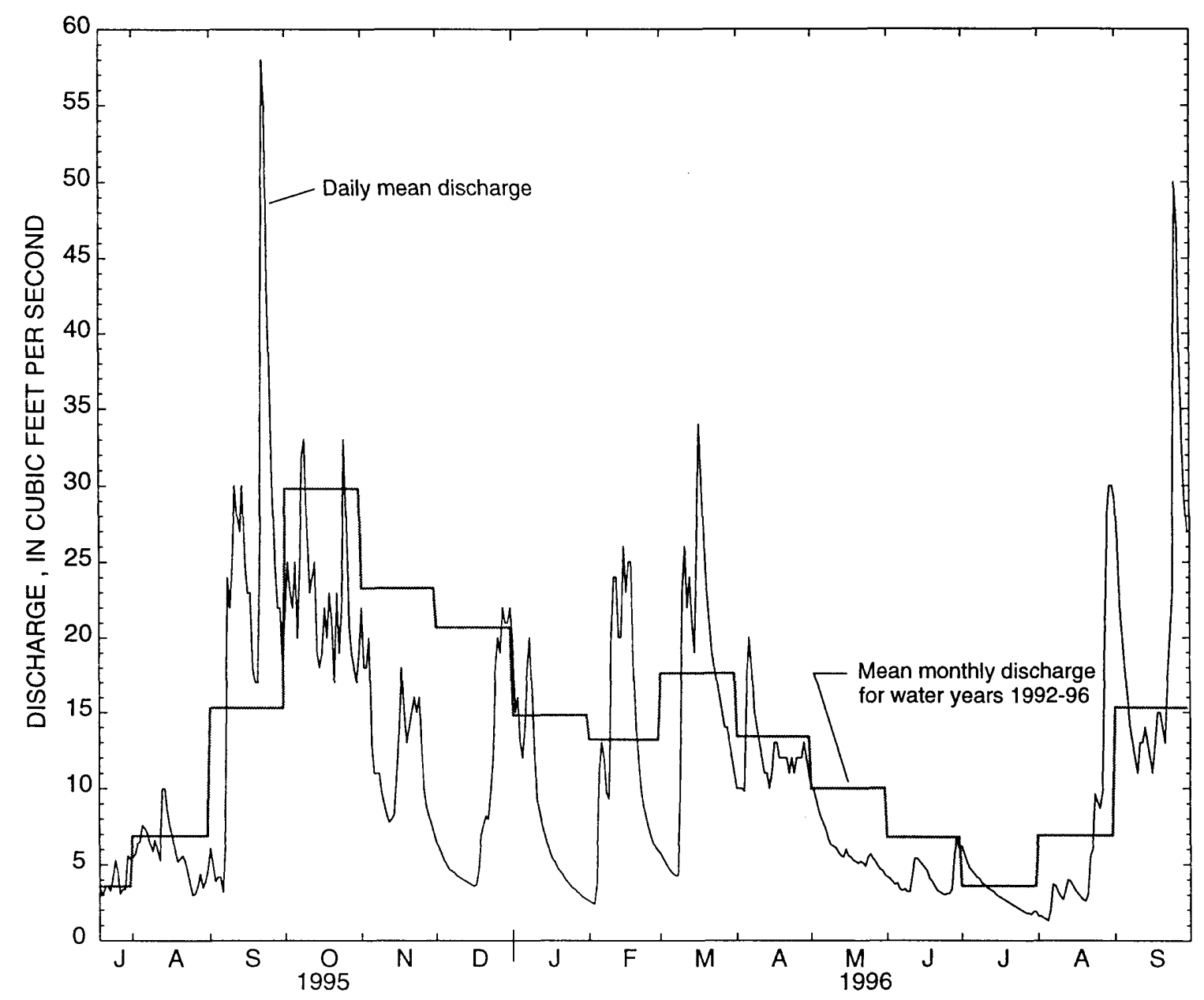

Figure 3. Daily mean discharge of Ophir Creek near Yakutat, Alaska (USGS gagingstation No. 15129600), July 1995 through September 1996, and mean monthly discharge. 
Table 3. Stream-discharge measurements at six sites in the Ophir Creek watershed, Alaska, and gains in stream discharge between sites, 1992-97

[All data in cubic feet per second; e, estimated; --, no data; NA, not applicable]

\begin{tabular}{|c|c|c|c|c|c|c|c|c|}
\hline \multirow{2}{*}{$\begin{array}{l}\text { Site } \\
\text { (fig. } \\
\text { 2) }\end{array}$} & \multicolumn{2}{|c|}{ April 11, 1992} & \multicolumn{2}{|c|}{ October 25,1992} & \multicolumn{2}{|c|}{ May 28,1993} & \multicolumn{2}{|c|}{ July 14,1993} \\
\hline & Discharge & Gain & Discharge & Gain & Discharge & Gain & Discharge & Gain \\
\hline $\bar{A}$ & 1 & NA & 6.2 & NA & -- & $\mathrm{NA}$ & 0 & NA \\
\hline B & 6.2 & 5.2 & 18 & 11.8 & 0.2 & -- & 0 & -- \\
\hline C & 13 & 6.8 & 35 & 17 & 2.1 & 1.9 & 0.2 & 0.2 \\
\hline D & 15 & 2 & 39 & 4 & 4.3 & 2.2 & 0.8 & 0.8 \\
\hline E & -- & -- & -- & -- & -- & .. & -- & -- \\
\hline F & 3.2 & NA & -- & NA & 0.4 & NA & -- & NA \\
\hline
\end{tabular}

\begin{tabular}{|c|c|c|c|c|c|c|c|c|}
\hline \multirow{2}{*}{$\begin{array}{l}\text { Site } \\
\text { (fig. } \\
2 \text { ) }\end{array}$} & \multicolumn{2}{|c|}{ August 17, 1993} & \multicolumn{2}{|c|}{ October 18,1993} & \multicolumn{2}{|c|}{ July 18,1994} & \multicolumn{2}{|c|}{ September 20,1995} \\
\hline & Discharge & Gain & Discharge & Gain & Discharge & Gain & Discharge & Gain \\
\hline A & 0 & $\mathrm{NA}$ & 3.8 & NA & 0 & NA & 5 & NA \\
\hline B & 0 & 0 & 12 & 8.2 & 0 & 0 & 7.7 & 2.7 \\
\hline $\mathrm{C}$ & $<0.2 \mathrm{e}$ & $<0.2 \mathrm{e}$ & 23 & 11 & 3.1 & 3.1 & 16.2 & 8.5 \\
\hline $\mathrm{D}$ & 0.9 & 0.7 & 30 & 7 & 5.2 & 2.1 & ${ }^{\mathrm{a}} 17$ & 0.8 \\
\hline E & 1.5 & 0.6 & 38 & 8 & 4.7 & -0.5 & -- & -- \\
\hline $\mathrm{F}$ & -- & NA & 14 & NA & 1.2 & $\mathrm{NA}$ & 4.6 & NA \\
\hline
\end{tabular}

\begin{tabular}{|c|c|c|c|c|c|c|c|c|}
\hline \multirow{2}{*}{$\begin{array}{l}\text { Site } \\
\text { (fig. - } \\
2 \text { ) }\end{array}$} & \multicolumn{2}{|c|}{ January 10, 1996} & \multicolumn{2}{|c|}{ March 7, 1996} & \multicolumn{2}{|c|}{ April 22, 1996} & \multicolumn{2}{|c|}{ June 20, 1996} \\
\hline & Discharge & Gain & Discharge & Gain & Discharge & Gain & Discharge & Gain \\
\hline A & 2.3 & NA & 1.2 & NA & 2.6 & $\mathrm{NA}$ & 0 & NA \\
\hline B & -- & -- & -- & -- & -- & -- & 0 & 0 \\
\hline $\mathrm{C}$ & 6.5 & 4.2 & 2.6 & 1.4 & 8.4 & 5.8 & 2 & 2 \\
\hline D & 9.3 & 2.8 & 4.3 & 1.7 & 11.4 & 3 & 3.3 & 1.3 \\
\hline $\mathrm{E}$ & -- & -- & -- & -- & -- & -- & -- & -- \\
\hline $\mathrm{F}$ & $\mathrm{b}_{1.5}$ & NA & $c_{0.3}$ & NA & 2.3 & NA & 0.3 & NA \\
\hline
\end{tabular}

\begin{tabular}{|c|c|c|c|c|c|c|c|c|c|c|}
\hline \multirow{2}{*}{$\begin{array}{l}\text { Site } \\
\text { (fig. } \\
\text { 2) }\end{array}$} & \multicolumn{2}{|c|}{ August 21, 1996} & \multicolumn{2}{|c|}{ October 7, 1996} & \multicolumn{2}{|c|}{ January 2, 1997} & \multicolumn{2}{|c|}{ April 8, 1997} & \multicolumn{2}{|c|}{ May 16,1997} \\
\hline & Discharge & Gain & Discharge & Gain & Discharge & Gain & Discharge & Gain & Discharge & Gain \\
\hline A & 0 & NA & 7.2 & NA & 2.2 & NA & 4 & NA & 6.4 & NA \\
\hline B & 0 & 0 & 8.6 & 1.4 & 0.5 & -1.7 & 2.3 & -1.7 & 6.8 & 0.4 \\
\hline C & 1.2 & 1.2 & 16 & 7.4 & 3.1 & 2.6 & 7.3 & 5 & 14.2 & 7.4 \\
\hline D & 3.1 & 1.9 & 20.5 & 4.5 & 5.4 & 2.3 & 10.2 & 2.9 & 18 & 3.8 \\
\hline E & -- & -- & -- & -- & -- & -- & -- & -- & -- & -- \\
\hline $\mathrm{F}$ & 0.2 & NA & -- & NA & 0.7 & NA & 2.93 & NA & 5 & NA \\
\hline
\end{tabular}

${ }^{\mathrm{a}}$ Mean daily discharge from gaging station

banuary 11

${ }^{\mathrm{c}}$ March 8

8 Hydrologic Investigation of the Ophir Creek Watershed Near Yakutat, Alaska 


\section{GROUND WATER}

Ground-water movement in the Yakutat Foreland is generally to the south or southwest, following the topography toward streams, lakes, and drains (Holmes and Dorava, 1995, p. 11). A surface drainage divide about 2 miles northeast of the airport (fig. 2) may also serve as the eastern ground-water divide for the Ophir Creek system. Stream-discharge measurements indicate that Ophir Creek generally gains flow from ground-water sources, but these data also indicate that some reaches lose water to the ground-water system.

Total ground-water withdrawals from wells within and near the watershed are estimated to average less than 220 gallons per minute, or 0.5 cubic foot per second. This estimate is based on a total of 160 gallons per minute from public supply wells in Yakutat (Alaska Department of Community and Regional Affairs, 1983) and a total of less than 60 gallons per minute from privately owned wells (Holmes and Dorava, 1995, p. 12). Ground-water discharge by evapotranspiration, which occurs throughout the study area, is probably only significant to Ophir Creek flows during the spring and summer. Data on evapotranspiration from soils and plants are not available to estimate ground-water discharge from evapotranspiration.

Recharge of ground water in the glacial and outwash deposits in the Ophir Creek watershed comes primarily from the infiltration of rainfall and snowmelt. Yehle (1979) has indicated that these deposits have good-to-excellent permeability. Drilling logs from the seven monitoring wells (appendix 1) indicate that gravel is the predominant near-surface rock type. This condition should allow fast infiltration of snowmelt and precipitation, and (if a sufficient hydraulic gradient exists) the rapid movement of water through the aquifer. Recharge is probably highest during and immediately following periods of heavy precipita- tion. Streamflow records for water years 198996 (U.S. Geological Survey, 1990-97) from USGS gaging stations Ophir Creek near Yakutat and Situk River near Yakutat (No. 15129500; fig. 1), show that the highest monthly mean flows occur in October.

\section{Well Construction}

During May 1995, six monitoring wells (wells 2-7, fig. 2 and table 4) were constructed in the Ophir Creek watershed and one monitoring well (well 1) was constructed in the watershed immediately to the northwest of the Ophir Creek watershed. A solid-stem steel auger was used to drill 3-inch diameter holes, within which 1.25 -inch-diameter steel casings were placed. Drill cuttings were logged and bit action was noted during the drilling. Each borehole was initially drilled to a depth between 21 and 30 feet, and a 3 -foot steel screen was placed below the water table using a steel drive point. After each well casing was in place, the space surrounding the casing was backfilled with native materials and sealed with a bentonite cap. Well logs and construction details for each monitoring well are given in appendix 1 .

\section{Ground-Water Levels}

Water levels in wells were measured weekly by personnel from the City and Borough of Yakutat and intermittently by USGS personnel from July 1995 to October 1996. Water levels measured after October 1, 1996 are shown in appendix 2 . The water level in a well was determined by using a steel tape to measure distance to the water surface from a known measuring point on the top of the steel casing. Replicate measurements were taken at each well until depth-to-water readings were duplicated within 0.01 foot. For each well, the elevation of the water-level measuring point (with respect to sea level) was determined by surveys in the summer of 1995 and the spring of 1997. 
Table 4. Information about monitoring wells in the Ophir Creek watershed, Alaska

\begin{tabular}{|c|c|c|c|c|c|c|c|c|c|}
\hline \multirow{2}{*}{$\begin{array}{l}\text { Well } \\
\text { No. } \\
\text { (fig. 2) }\end{array}$} & \multirow{2}{*}{ USGS site ID } & \multirow{2}{*}{ USGS local number } & \multirow{2}{*}{$\begin{array}{c}\text { Elevation of } \\
\text { land- } \\
\text { surface } \\
\text { datum } \\
\text { (feet above } \\
\text { sea level) }\end{array}$} & \multicolumn{2}{|c|}{$\begin{array}{l}\text { Screen opening } \\
\text { (feet below land } \\
\text { surface) }\end{array}$} & \multicolumn{4}{|c|}{$\begin{array}{c}\text { Water level } \\
\text { (feet above sea level) }\end{array}$} \\
\hline & & & & Top & Bottom & Highest & Date & Lowest & Date \\
\hline 1 & 593145139443301 & CD02703336DBCB1 & 29.3 & 21.2 & 24.2 & 29.06 & $11 / 1 / 95$ & 22.15 & $6 / 24 / 96$ \\
\hline 2 & 593216139434101 & CD02703431BDBB1 & 37.0 & 15.6 & 18.6 & 37.74 & 10/11/95 & 34.20 & $7 / 28 / 95$ \\
\hline 3 & 593304139412001 & CD02703429BBCA1 & 51.3 & a8.1 & a 8.1 & 55.90 & $3 / 11 / 96$ & $\mathrm{~b}<43.2$ & $8 / 5-19 / 96$ \\
\hline 4 & 593226139420201 & $\mathrm{CD} 02703429 \mathrm{DCCC} 1$ & 50.3 & 14.2 & 17.2 & 48.37 & $7 / 12 / 95$ & 43.75 & $8 / 27 / 96$ \\
\hline 5 & 593157139424201 & CD02703431DDCA1 & 45.7 & 15.6 & 18.6 & 45.80 & $9 / 22 / 95$ & 38.17 & $8 / 19 / 96$ \\
\hline 6 & 593146139440901 & CD02703336DBDD1 & 31.0 & 14 & 17 & 28.12 & 9/22/95 & 25.26 & $7 / 29 / 96$ \\
\hline 7 & 593218139431501 & CD02703431CAAB1 & 47.4 & 23.6 & 26.6 & 40.66 & 9/22/95 & 35.99 & $8 / 19 / 96$ \\
\hline
\end{tabular}

Well 1 is about 1.6 miles south of Yakutat and about 0.3 mile west of Ophir Creek (fig. 2). Well 1 is the only well monitored that does not lie within the Ophir Creek watershed. Water levels (fig. 4A) ranged from a low of 22.2 feet above sea level on June 24, 1996 to a high of 29.1 on November 1, 1995. An additional low water level of 22.2 feet was measured on August 5, 1996. The water levels in this well rise quickly following rain or snowmelt (fig. 5) and decline during prolonged dry or cold periods. Water levels in this well generally tracked, in time and direction, changes in streamflow at the Ophir Creek gaging station.

Well 2 is about 1 mile south of Yakutat and about 200 feet east of Ophir Creek (fig. 2). Water levels in well 2 (fig. 4B) ranged from a low of 34.2 feet above sea level on July 28, 1995 to a high of 37.7 feet on October 11, 1995. Well 2 had the second smallest range in water levels (3.5 feet). This well was the only one observed that reached its lowest measured water level in the summer of 1995 . The other six wells had minimum water levels in the summer of 1996. Water levels in well 2 did not show sharp responses to precipitation. Peaks occurred in October and November 1995, probably in response to increased rainfall during these months (fig. 5). Water levels then gradually declined through early August 1996, and began to rise again in late August 1996.

Well 3 is about 1.7 miles east of Yakutat and about 0.3 mile northwest of a remnant Ophir Creek channel (fig. 2). This well was installed in an excavated pit and ground-water levels intermittently rise above land surface during periods of heavy rainfall or snowmelt. The well casing in well 3 is broken 11.4 feet below the measuring point and the water levels were below this elevation (43.2 feet above sea level) from August 5-19, 1996. The peak water level measured was 55.9 feet above sea level on March 11, 1996 (fig. 4C) and is attributed to rain and snowmelt in February and early March. Water levels in well 3 had the largest range (more than 12.7 feet) of the seven wells measured. The water levels in this well show rises and declines in response to precipitation (fig. 5). Water levels in well 3 tend to track, in time and direction, changes in streamflow of Ophir Creek. 

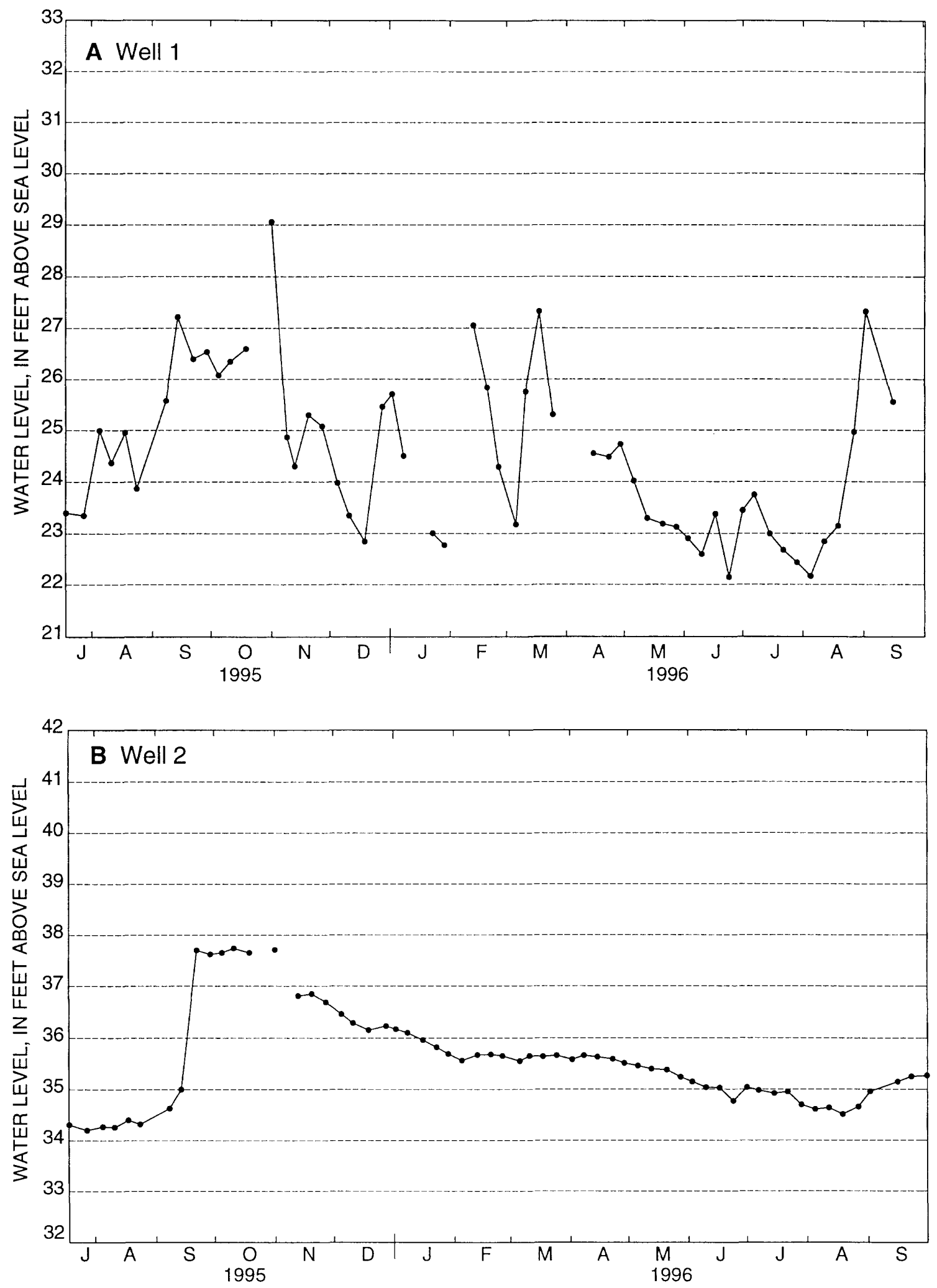

Figure 4. Water levels, July 1995 through September 1996, wells 1 to 7. 

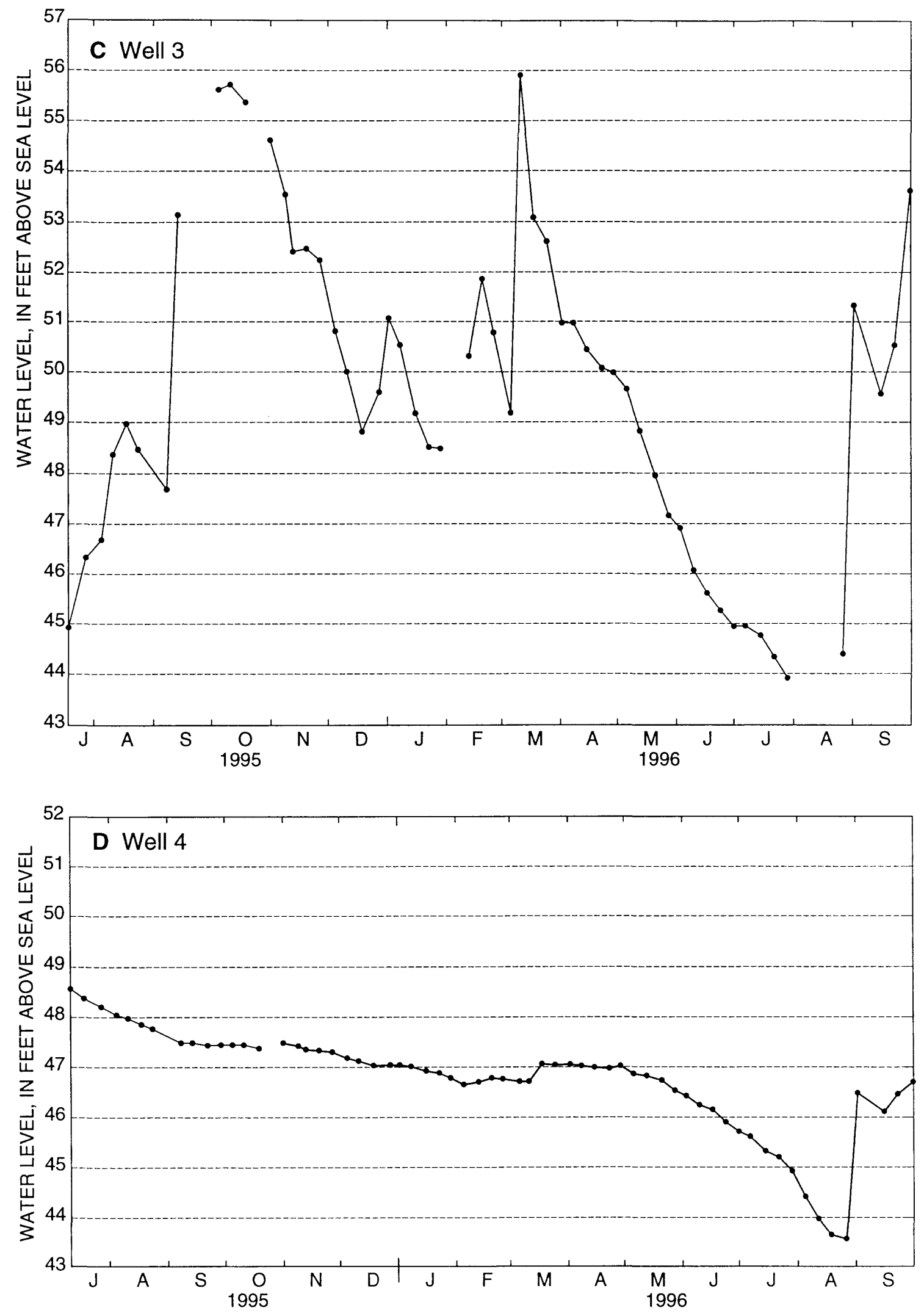

Figure 4. Continued. 

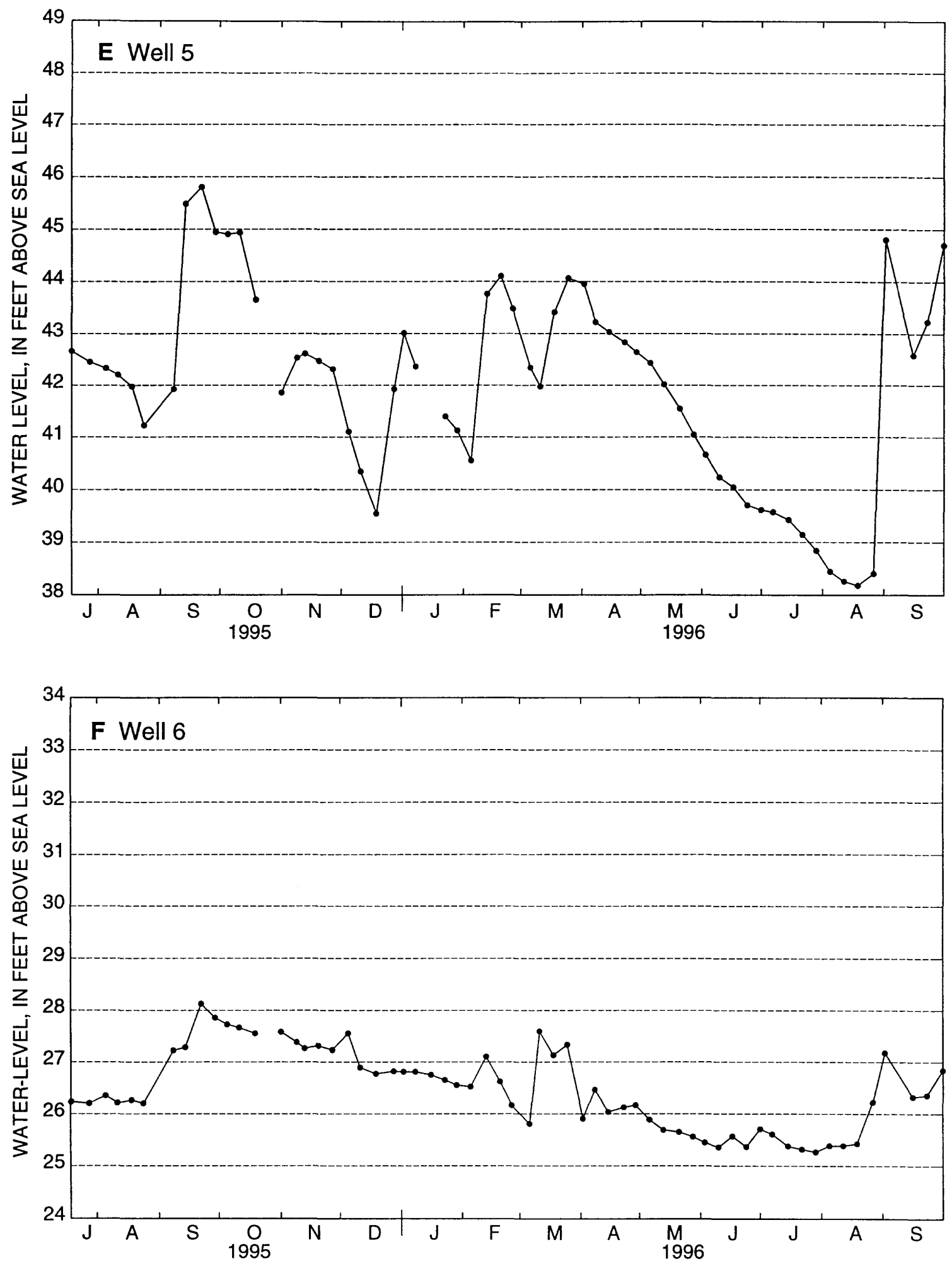

Figure 4. Continued. 


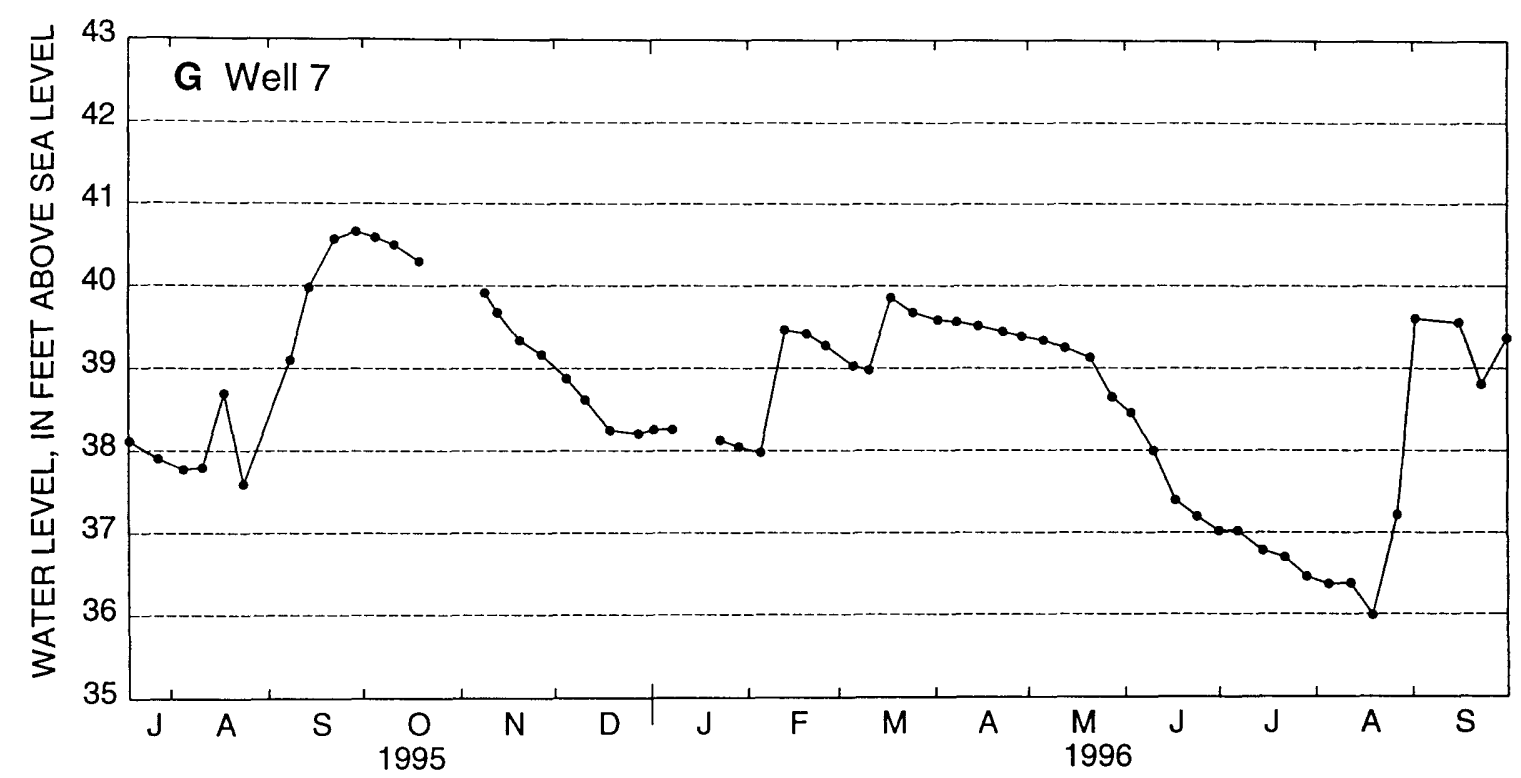

Figure 4. Continued.

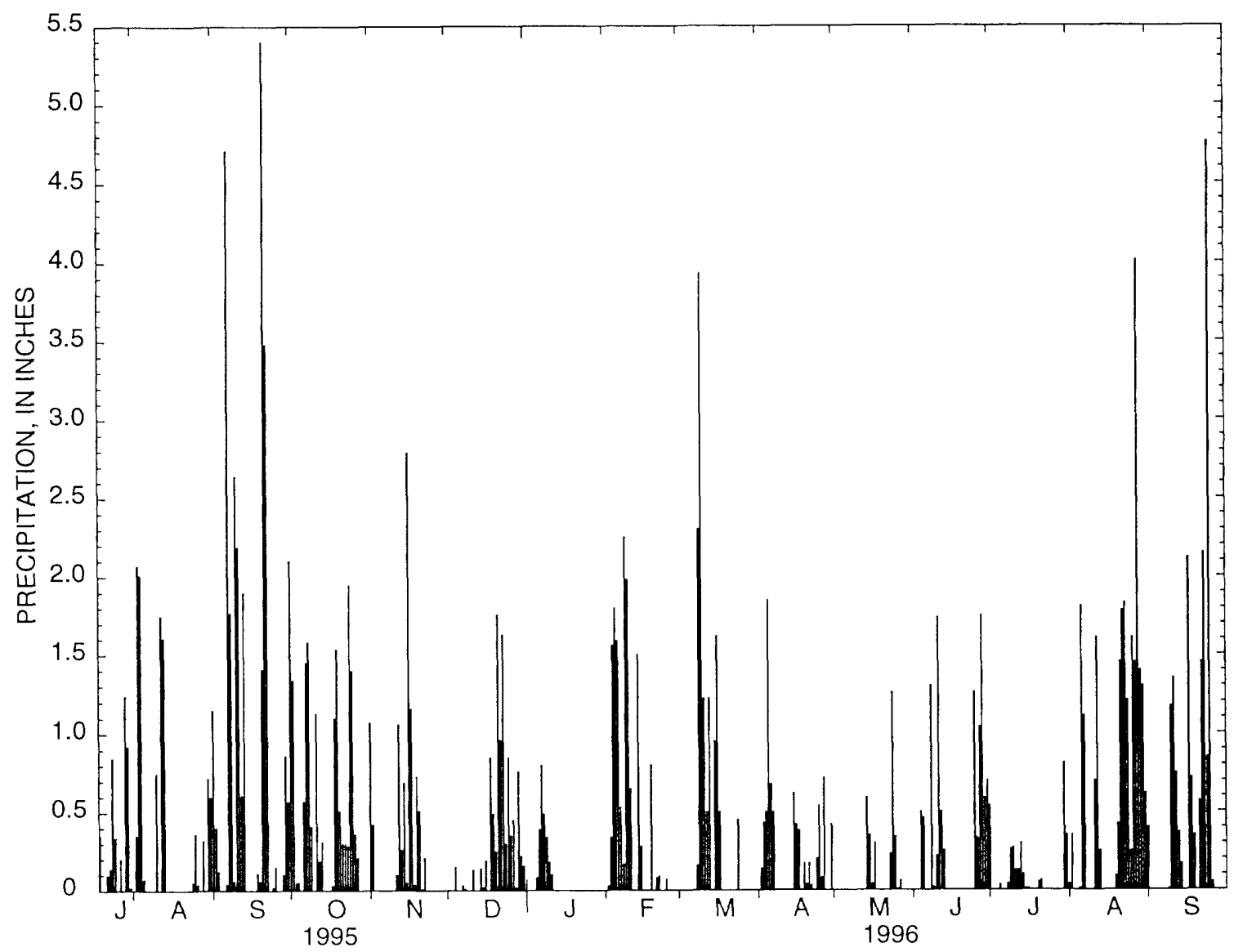

Figure 5. Daily precipitation at Yakutat Airport, July 1995 through September 1996. 
Well 4 is about 1.5 miles southeast of Yakutat and about 60 feet north of the Ophir Creek channel (fig. 2). Water levels in well 4 (fig. 4D) ranged from a low of 43.6 feet above sea level on August 27, 1996 to a high of 48.6 feet on July 19, 1995. Water levels in well 4 did not follow the same trends shown in the other six wells. This condition was probably due to the influence of an experimental excavation project adjacent to the well (see "Experimental Excavation" section later in report). A 2,000foot-long reach of stream channel (fig. 2) was deepened in August 1995 and seemed to function as a drain, lowering the water table in the vicinity of the excavation. The hydrograph of well 4 (fig. 4D) shows a gradual decline in water level from July 1995 through August 1996. The pattern of water-level changes from October 1996 through March 1997 (see appendix 2) closely follow those of wells $1,5,6$, and 7.

Well 5 is about 1.6 miles southeast of Yakutat and about 0.2 mile southwest of the road from Yakutat to the airport (fig. 2); it is about 100 feet west of a tributary to Ophir Creek. Water levels in well 5 (fig. 4E) ranged from a low of 38.2 above sea level on August 19,1996 to a high of 45.8 feet on September 22, 1995 (coincident with highest daily mean discharge at Ophir Creek gaging station). The water levels in this well showed rises corresponding to recharge from precipitation (fig. 5), and declines during prolonged dry or cold periods. Water levels in this well generally track, in time and direction, changes in streamflow at the Ophir Creek gaging station.

Well 6 is about 1.7 miles south of Yakutat and about 45 feet west of Ophir Creek (fig. 2); it is about 0.8 mile downstream from well 2 and about 0.5 mile upstream from the gaging station on Ophir Creek (site D). Water levels in well 6 (fig. 4F) ranged from a low of 25.3 feet above sea level on July 29, 1996 to a high of 28.1 feet on September 22, 1995. Well 6 had the smallest range in water-level fluctuation (2.9 feet) of the seven wells monitored. The July 29, 1996 measurement coincided with the annual 7-day minimum flow on Ophir Creek that began on July 30 (average flow was 1.6 cubic feet per second). The September 22, 1995, measurement was made on the same day as the highest daily mean discharge of Ophir Creek for the 1995 water year (58 cubic feet per second). Water levels in well 6 tend to closely track, in time and direction, streamflow in Ophir Creek. Periods of low stream discharge without corresponding declines in water level occurred during December 1995 and January 1996. Climate data and ice-affected stage records indicated that these were periods of extreme cold ( -11 to $23{ }^{\circ} \mathrm{F}$ ) and ground-water discharge to the stream was probably temporarily stored in the form of ice.

Well 7 is about 1.1 miles south of Yakutat and about 0.2 mile southeast of Ophir Creek (fig. 2) near what appears to be a remnant tributary channel of the creek. Water levels in well 7 (fig. 4G) ranged from a low of 36.0 feet above sea level on August 19, 1996 to a high of 40.7 feet on September 29, 1995. Water levels in well 7 show rises with heavy or prolonged precipitation (fig. 5), but do not show the same sharp response to isolated storms shown by wells $1,3,6$, and 5. Water levels in well 7 generally tracked streamflows in Ophir Creek.

In summary, during the period of groundwater levels observations from July 1995 to October 1996, water levels in the seven monitoring wells ranged from 2.9 feet above land surface in well 3 to 11.4 feet below land surface in well 7. Fluctuations of water levels in wells ranged from 2.9 feet in well 6 to 12.7 feet in well 3 and averaged 6.2 feet. The data indicated that streamflow in Ophir Creek was closely tied to water levels in the surrounding aquifer. With the exception of well 4 , the highest water-level measurements in all wells coincided with high streamflow discharges in Ophir Creek. Both maximum and minimum water levels in wells 6 coincided with maximum and minimum streamflows in Ophir Creek, respectively. Wells 2 and 6, which are closest to groundwater discharge points (Ophir Creek), had the least range of water levels. 


\section{SURFACE WATER/GROUND WATER INTERACTIONS}

\section{Yakutat Foreland Aquifer}

The shallow ground-water system in the Yakutat Foreland is a water-table aquifer fed by infiltration of precipitation and drained by numerous small streams, including Ophir Creek. Aquifer conditions similar to those in the Yakutat Foreland have been described in numerous theoretical models (Werner, 1957;
Glover, 1960; Freeze and Cherry, 1979; Fetter, 1980). In such a system, the aquifer is recharged at its surface by infiltration of precipitation (fig. 6A). This water then flows downward and toward the boundary streams where it discharges. When ground-water levels are high, the corresponding stream discharge will be larger, and when the ground-water levels are low, stream discharges will decrease. In the Yakutat Foreland, however, there are not two, but many streams resulting in numerous flow systems (fig. 6B).
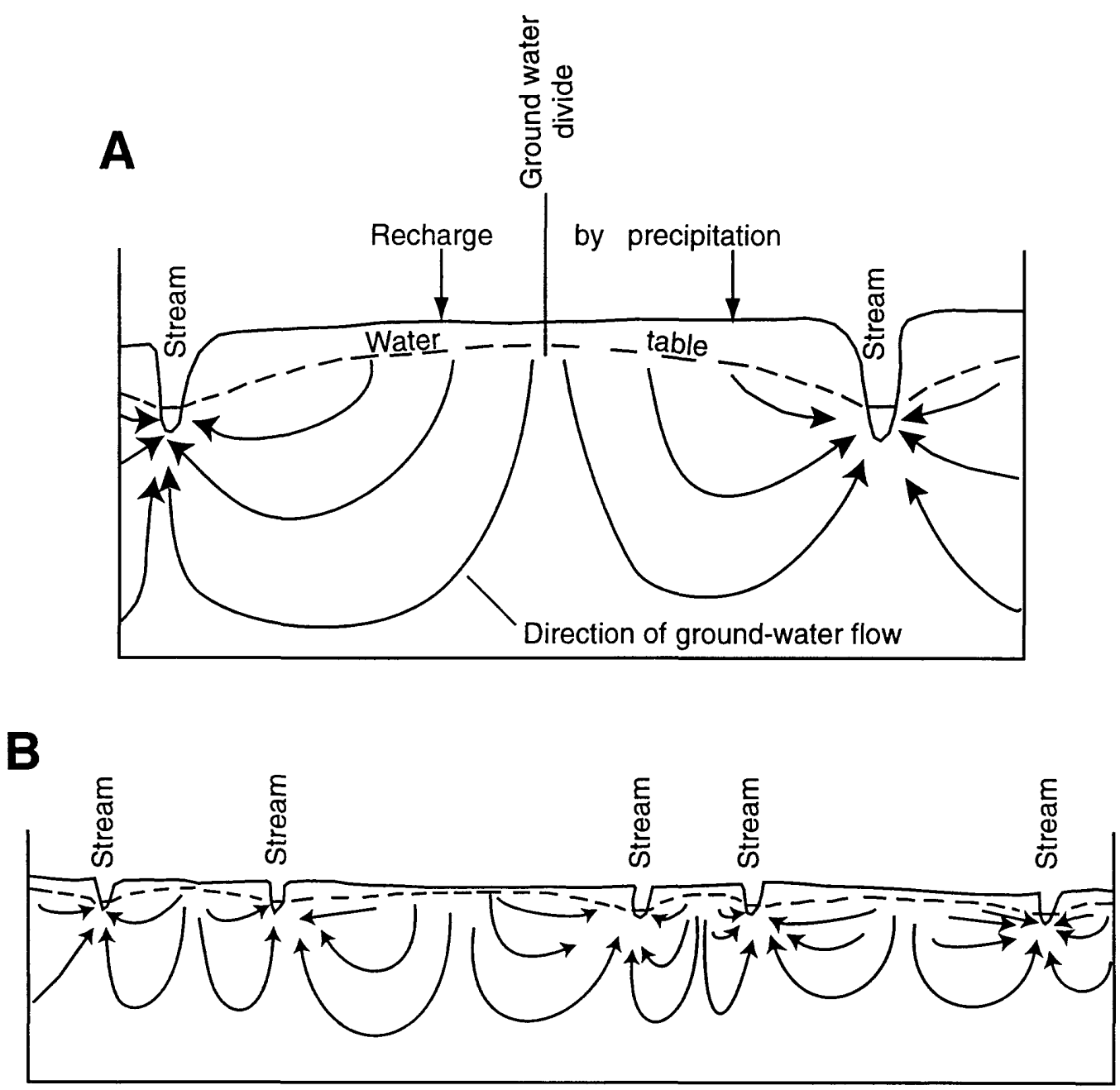

Figure 6. Generalized ground-water flow in a homogenous water-table aquifer having two streams (A) and numerous streams (B). 
If an aquifer discharges water only to streams, and recharge is intermittent, the watertable fluctuations will be largest near the ground-water divides and smallest near the streams. The stages of the streams change with streamflow. Aquifers can also be recharged by streams when the stage of streams is higher than the local water table. The water table immediately adjacent to the streams tends to fluctuate synchronously with changing stage, and the aquifer gains or loses water to streams depending on the relative positions of stage and ground-water levels.

In the Yakutat Foreland aquifer, the largest fluctuations observed were in well 3 , which fluctuated more than 12 feet from maximum water level to minimum water level. Well 3 is relatively more distant from the boundary streams and closest to a divide, an area where large fluctuations would be expected. In contrast to well 3 , wells 2 and 6 are located close to
Ophir Creek and would be expected to fluctuate approximately the same as the stream stage. Well 6 fluctuated only 2.9 feet during the measurement period (fig. 4F). Well 2, approximately 200 feet from Ophir Creek, also showed small fluctuations with a range of 3.5 feet during the measurement period (fig. 4B).

The Yakutat Foreland aquifer, generalized in figure 6B, is in a long-term state of equilibrium in which the net recharge to the aquifer is nearly balanced by discharge from the streams. Net recharge is the precipitation minus the evaporation and transpiration from soils and vegetation and pumpage out of the aquifer. The quantity of ground water available to sustain flow in streams is therefore finite, and changes only in response to changes in precipitation, or changes in pumpage from the aquifer. If a ditch is excavated below the water table, it will conduct additional ground water out of the system (fig. 7). This additional
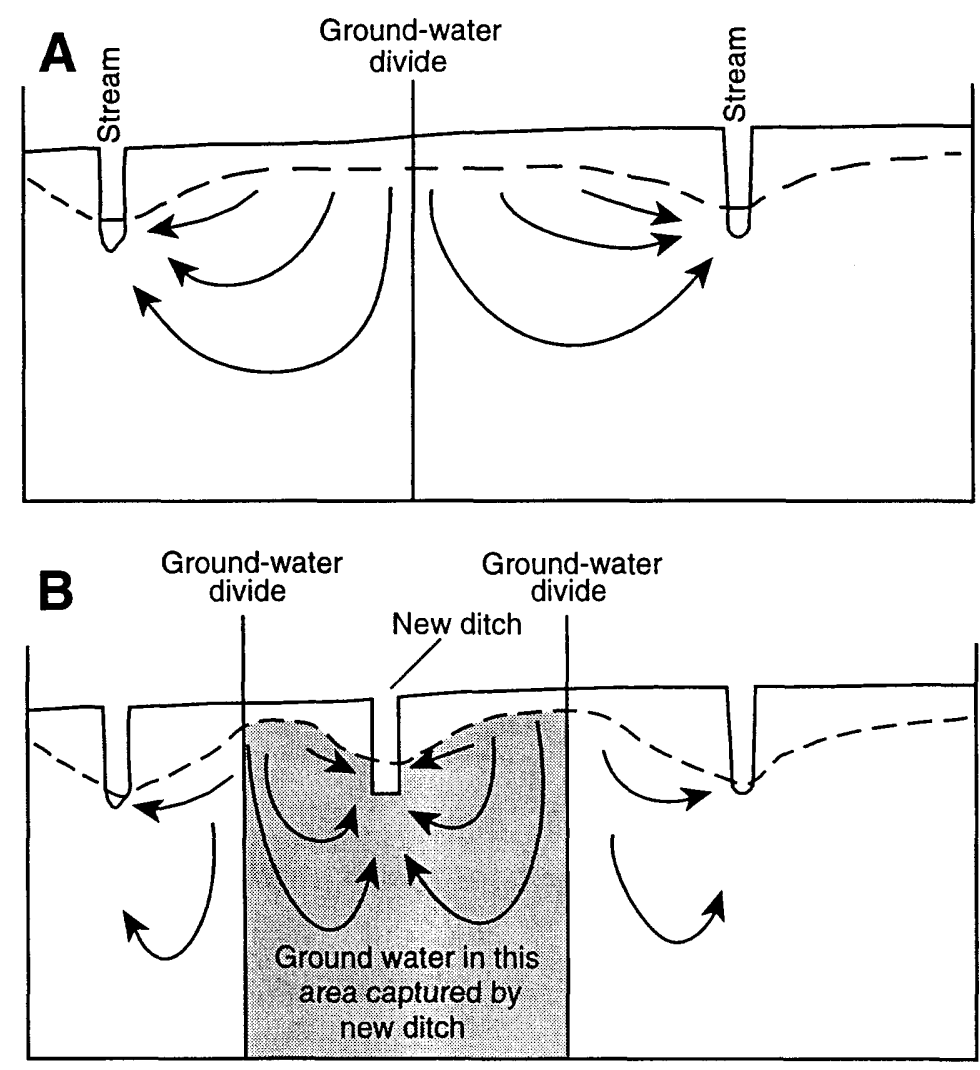

Figure 7. Generalized ground-water flow in a homogenous water-table aquifer before $(A)$ and after $(B)$ construction of a drainage ditch. 
ground water discharging into the ditch is captured ground water that would have flowed into an adjacent stream and will result in reduced flows in adjacent streams.

\section{Experimental Excavation}

The construction of drains or deepening of existing channels can affect water levels and the direction of ground-water flow. Drains can lower the water table in the region near the drain and create artificial discharge points for shallow ground water (Freeze and Cherry, 1979, p. 492). Excavations to deepen selected reaches of Ophir Creek's channel to intercept ground water is an experimental technique being used by the City and Borough of Yakutat
Salmon Enhancement Board in an attempt to restore perennial streamflow to intermittent reaches of the creek. Excavating an existing stream channel does not create a new source of water; it merely redistributes the ground water that is available, by capturing ground water from the basins of adjacent streams (fig. 8) or by redistributing the ground-water discharge to the streams.

Downstream from a reach where a channel has been excavated, the characteristics of stream discharge may change; for example, flows following a rainstorm may be slightly higher. However, the high flows may not last as long due to the reduction in aquifer storage. In addition, the increased streamflow results in higher stage, the higher stage raises the water
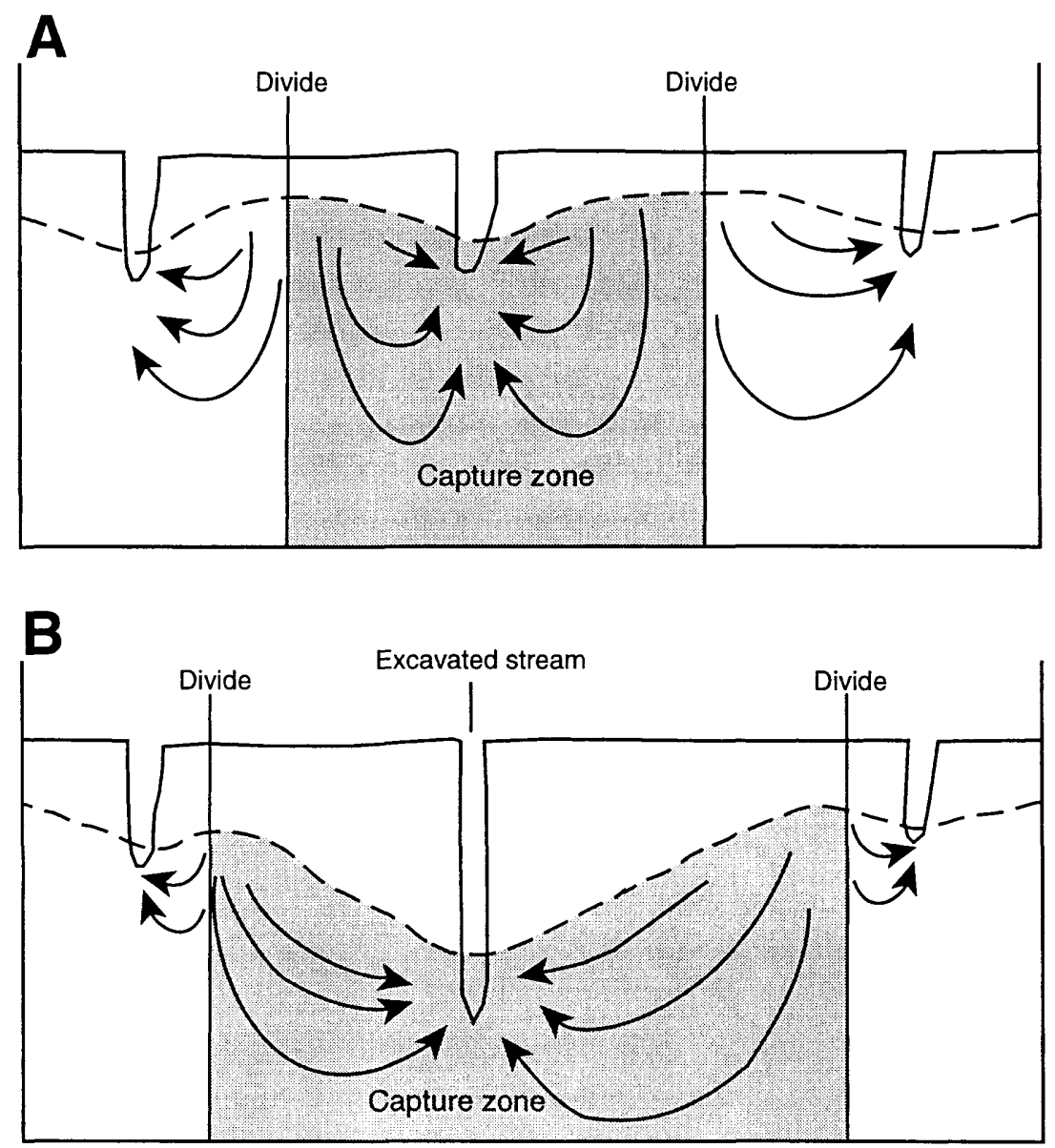

Figure 8. Generalized ground-water flow in a homogenous water-table aquifer before (A) and after (B) excavation of an existing stream channel. 
table near the stream channel, and the reverse of the phenomenon shown in figure 8 occurs. Downstream from the excavation, water may flow back into the aquifer and may be recaptured by adjacent streams.

In August 1995, a 2,000-foot-long reach of Ophir Creek channel was excavated under the direction of the City and Borough of Yakutat. The excavation extends approximately 800 feet downstream and 1,200 feet upstream from well 4 (fig. 2). Excavation depths ranged from 2 to 5 feet below the previously existing channel. As the upper part of Ophir Creek was deepened, the water table began to decline immediately as ground water flowed into the creek, as shown by the hydrograph of well 4 (fig. 4D). As the water table was lowered, the streamflow at site A (fig. 2) near the downstream end of the excavated reach initially increased (it was frequently dry prior to excavation). This initial increase in streamflow was a result of additional ground water being released from storage. As the volume of stored water declined, streamflow in this reach then decreased until a new steady-state condition was reached. Any increase in flows (relative to pre-excavation conditions) after this new equilibrium is reached will be a result of either the loss of streamflow from adjacent streams, or the decrease of ground-water discharges to downstream reaches of Ophir Creek.

Stream discharges measured since April 1992 (table 3) at sites A and B may indicate that the stream discharge generated as a result of the excavation is recharged to the aquifer between these points during periods of low flow. On January 2, 1997, discharge at site A was 2.2 cubic feet per second, and that at site B was 0.5 cubic foot per second. Discharges at these sites on April 8, 1997 also demonstrate loss of streamflow in this reach (1.7 cubic feet per second) at a slightly different flow regime.

While deepening the channel may increase the streamflow duration in the vicinity of the excavation, all additional streamflow may not be conveyed very far downstream as surface water. Discharges measured in January and April 1997 indicate that much of this flow is recharged back into the ground-water system downstream from the excavation. Intermittent flows of Ophir Creek can still be expected downstream from the excavation. Water-level measurements in well 4 (figs. 2 and 4D) indicated that ground-water levels declined as a result of the excavation. The base flow in Ophir Creek is generated from the surrounding aquifer. Reduced ground-water levels of the surrounding aquifer will result in a change in surface-water flow duration downstream from the excavation site.

\section{SUMMARY}

The shallow ground-water system in the Ophir Creek watershed is a water-table aquifer that is recharged by infiltration of precipitation and discharges to the stream. Stream discharges in Ophir Creek are closely related to water levels in the surrounding aquifer. With the exception of well 4, peak water levels of all wells coincided with peak surface-water discharges in Ophir Creek. Both maximum and minimum water levels in well 6 coincided with maximum and minimum streamflows in Ophir Creek. Wells located closest to Ophir Creek (wells 2, 4 , and 6) had the least fluctuations of water level (2.86 to 4.62 feet), whereas wells that were farther from ground-water-discharge areas had the greatest fluctuations of water level (6.9 to more than 12.7 feet). All measured ground-water levels were less than 11.4 feet below land surface.

Flows in Ophir Creek are sustained primarily through ground-water discharge into the stream. Daily mean discharges for the 2.5 square-mile-basin above the stream-gaging station have ranged from 0.27 to 81 cubic feet per second. The aquifer surrounding Ophir Creek is in a long-term state of equilibrium in which the net recharge is nearly balanced by discharge 
from the streams. The quantity of ground water available to sustain flow in streams is therefore finite, and changes only in response to changes in precipitation or pumpage from surrounding aquifers.

Although excavations that deepen the Ophir Creek channel may induce additional surface-water flow along the excavated reach and immediately downstream from it, not all of this water is necessarily conveyed through the entire downstream reach as surface water. Intermittent flows of Ophir Creek can still be expected downstream from the excavation. Reduced ground-water levels caused by the excavation will change the surface-water flow duration.

\section{REFERENCES CITED}

Alaska Department of Community and Regional Affairs, 1983, Yakutat: Alaska Department of Community and Regional Affairs Community Map-Yakutat, 1 sheet.

Bishop, D.M., 1986, Examination of culverts for Ophir Creek, near Yakutat: ENVIRONAID report, 50 p.

Fetter, C.W., 1980, Applied hydrogeology: Columbus, Ohio, Bell \& Howell Company, 488 p.

Freeze, R.A., and Cherry, J.A., 1979, Groundwater: Englewood Cliffs, N.J., Prentice-Hall, Inc., 604 p.
Glover, R.E., 1960, Studies of ground-water movement: U.S. Bureau of Reclamation Technical Memorandum $657,180 \mathrm{p}$.

Hartman, C.W., and Johnson, P.R., 1984, Environmental atlas of Alaska: University of Alaska Fairbanks, Institute of Water Resources/Engineering Experiment Station, 95 p.

Holmes, W.F., and Dorava, J.M., 1995, Overview of environmental and hydrogeologic conditions at Yakutat, Alaska: U.S. Geological Survey Open-File Report 94-713, 17 p.

Leslie, L.D., 1989, Alaska climate summaries (2d ed.): University of Alaska, Anchorage, Arctic Environmental Information and Data Center, Alaska Climate Center Technical Note 5.

National Oceanic and Atmospheric Administration, 1946-96, Climatological data for Alaska: U.S.Department of Commerce, issued annually.

U.S. Geological Survey, 1990-97, Water resources data for Alaska, water years 1989-96: U.S. Geological Survey Water-Data Reports, published annually.

Wahrhaftig, Clyde, 1965, Physiographic divisions of Alaska: U.S. Geological Survey Professional Paper $482,52 \mathrm{p}$.

Werner, P.W., 1957, Some problems in non-artesian ground-water flow: Transactions, American Geophysical Union, v. 38, no. 4, p. 511-518.

Yehle, L.A., 1979, Reconnaissance engineering geology of the Yakutat area, Alaska, with emphasis on evaluation of earthquake and other geologic hazards: U.S. Geological Survey Professional Paper 1074, $43 \mathrm{p}$. 


\section{APPENDIX 1}

Drilling Logs of Monitoring Wells 1-7 


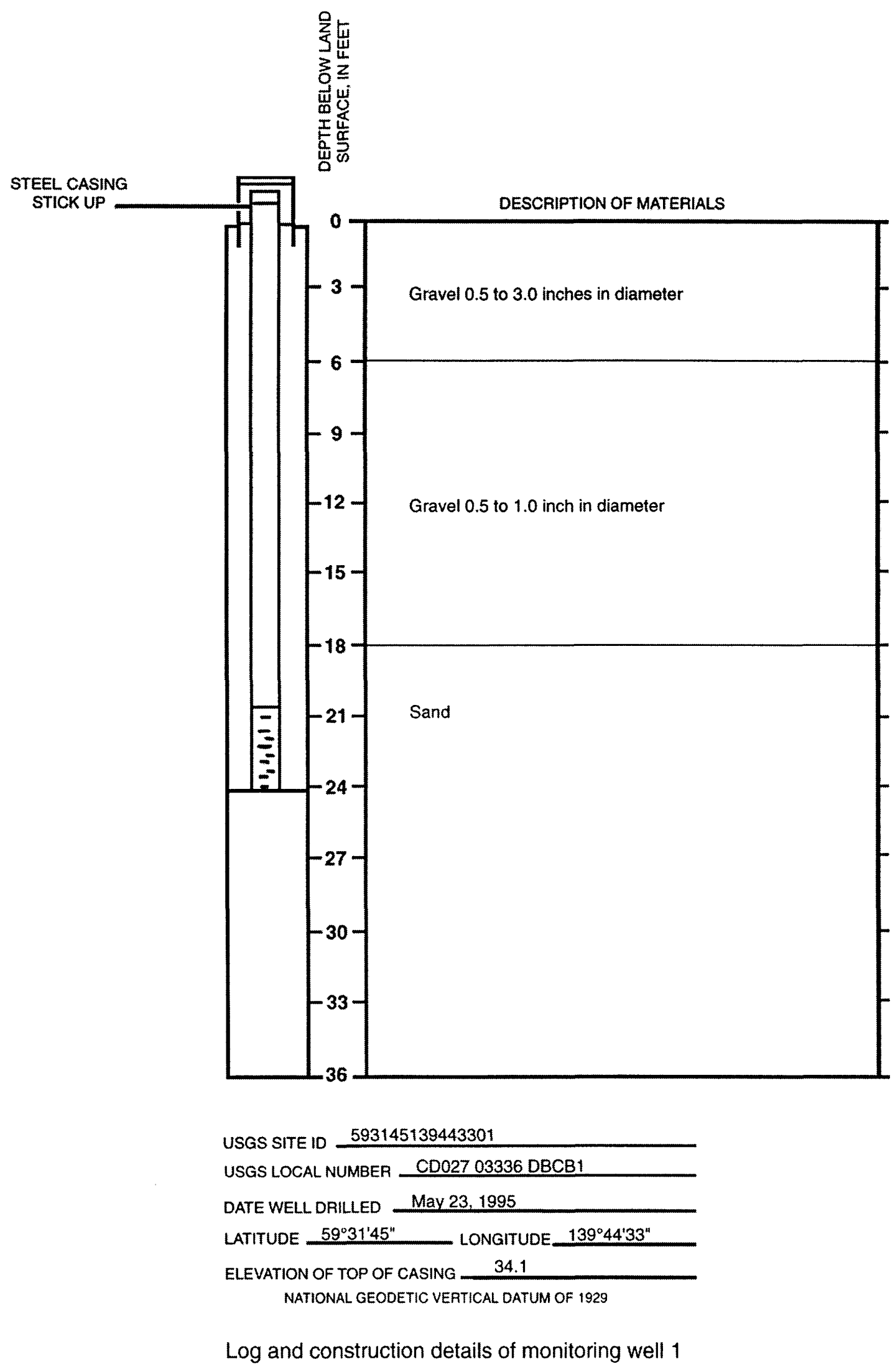




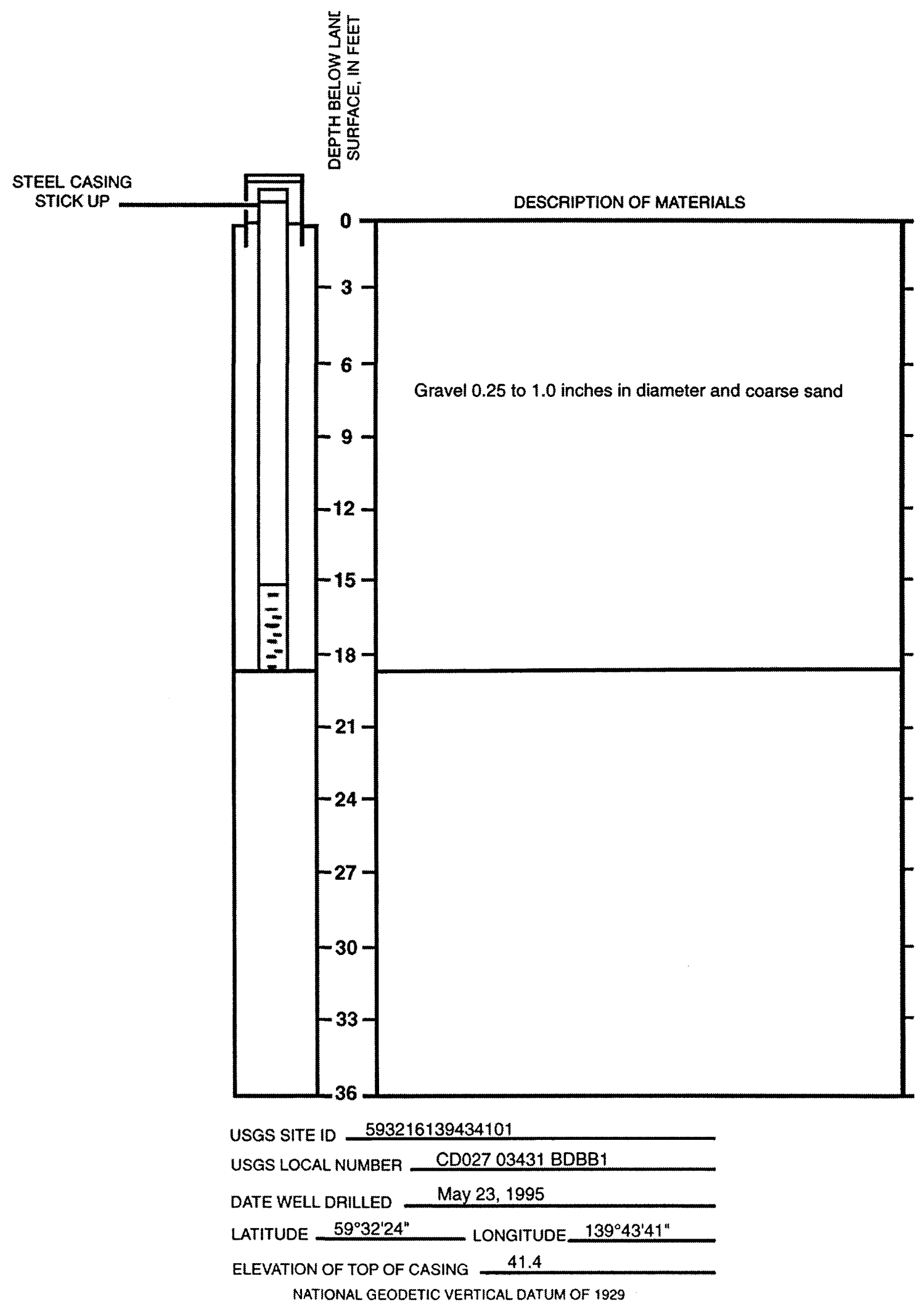

Log and construction details of monitoring well 2 


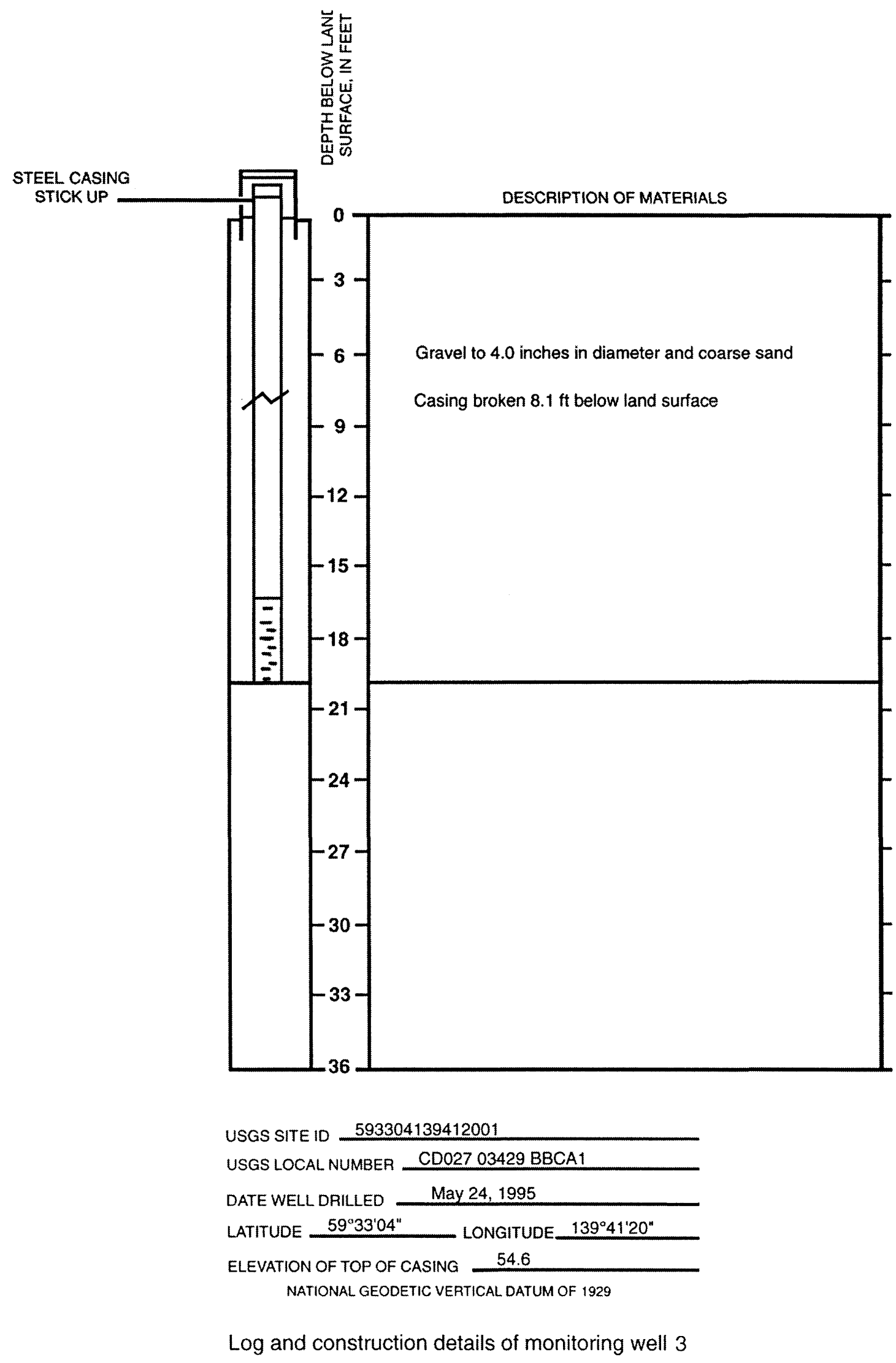

24 Hydrologic Investigation of the Ophir Creek Watershed Near Yakutat, Alaska 


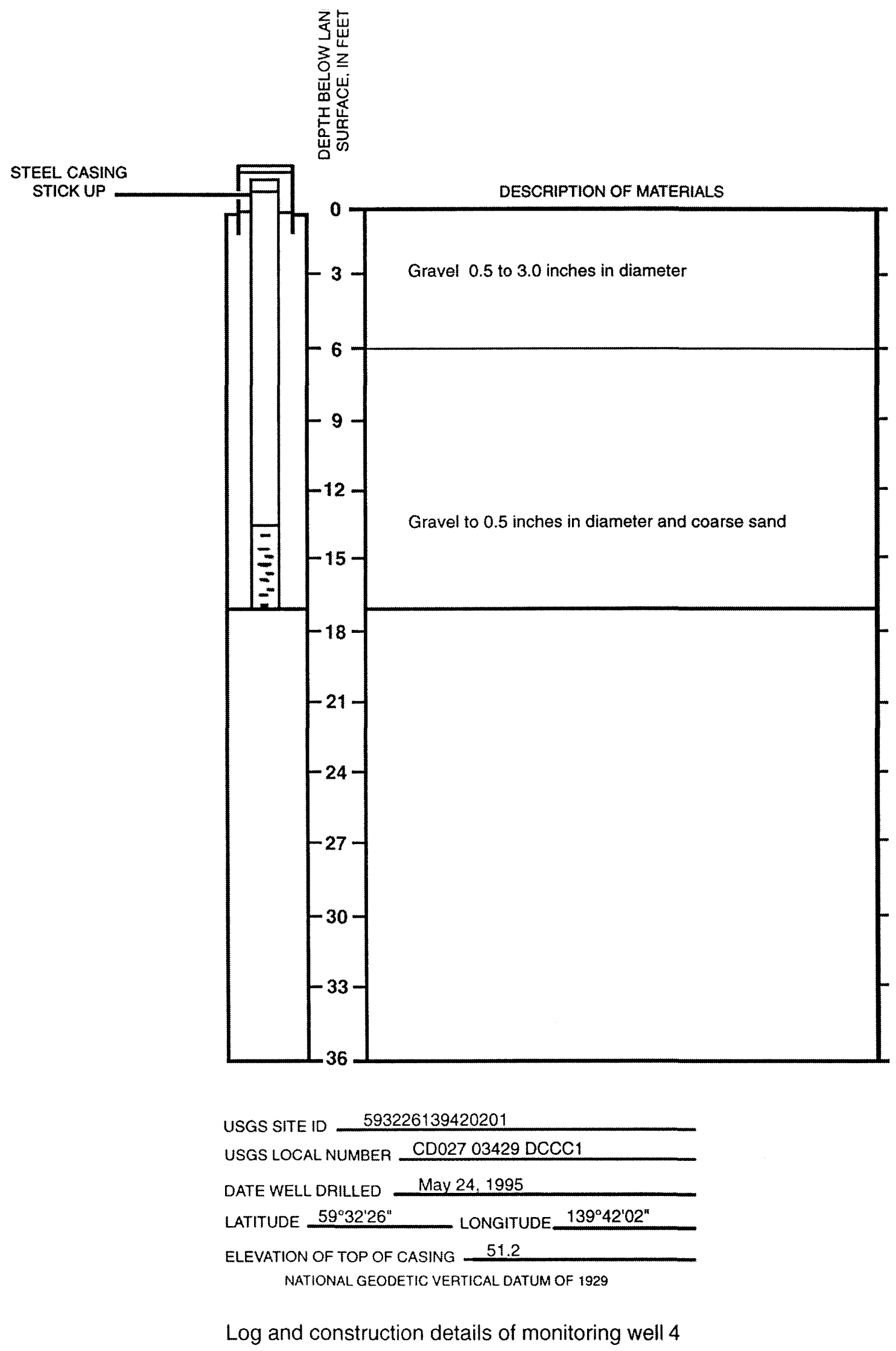




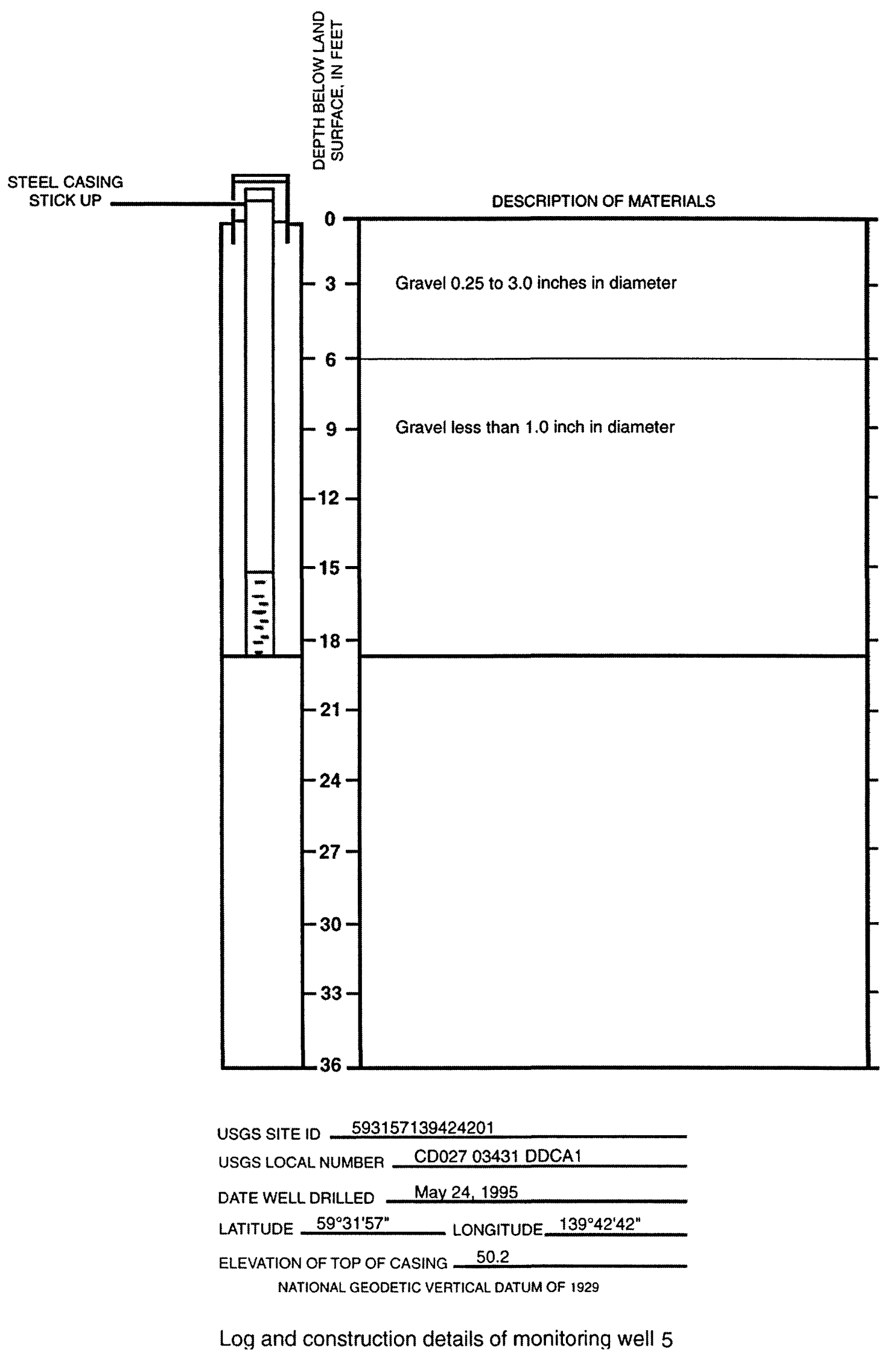




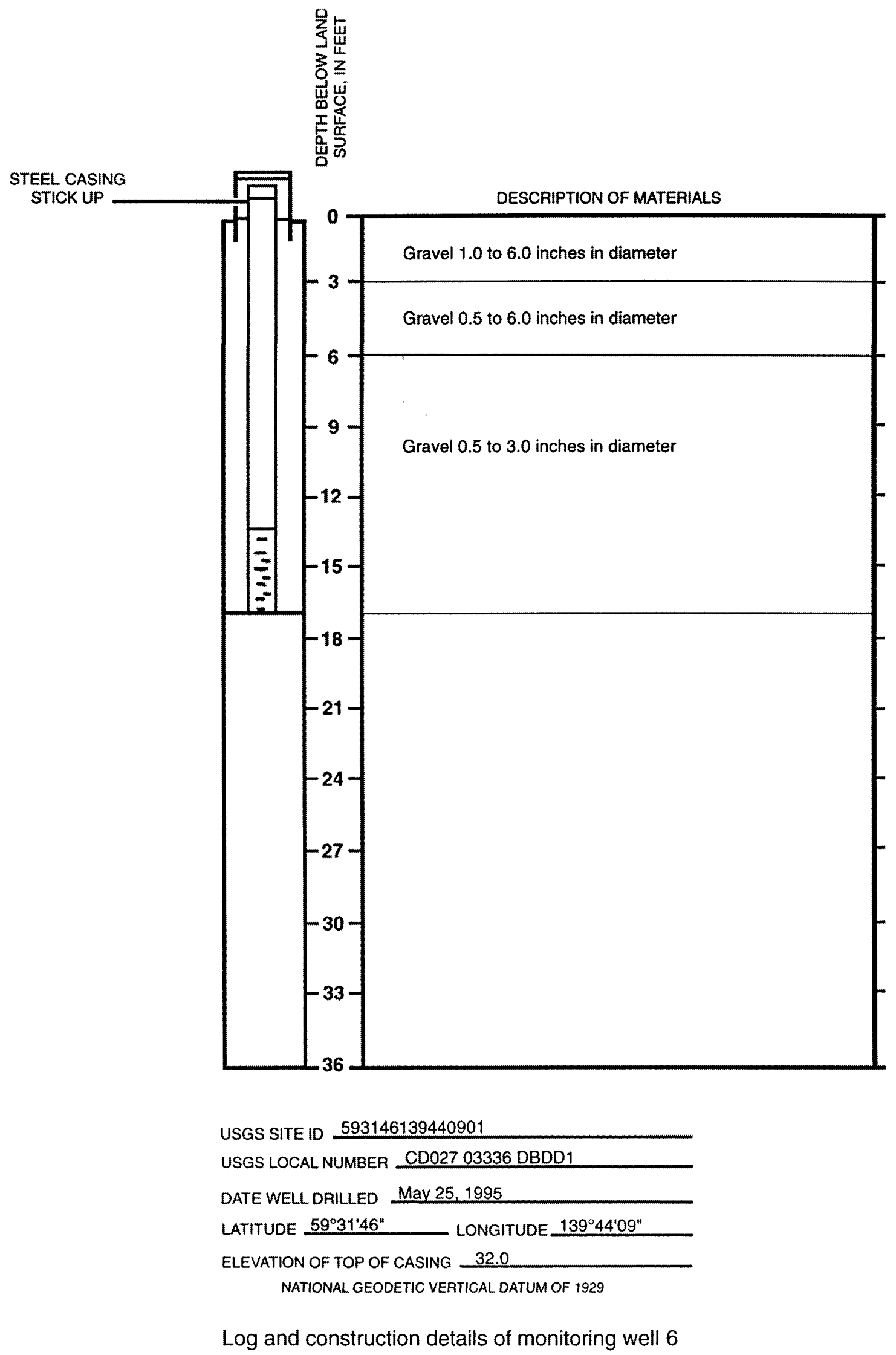




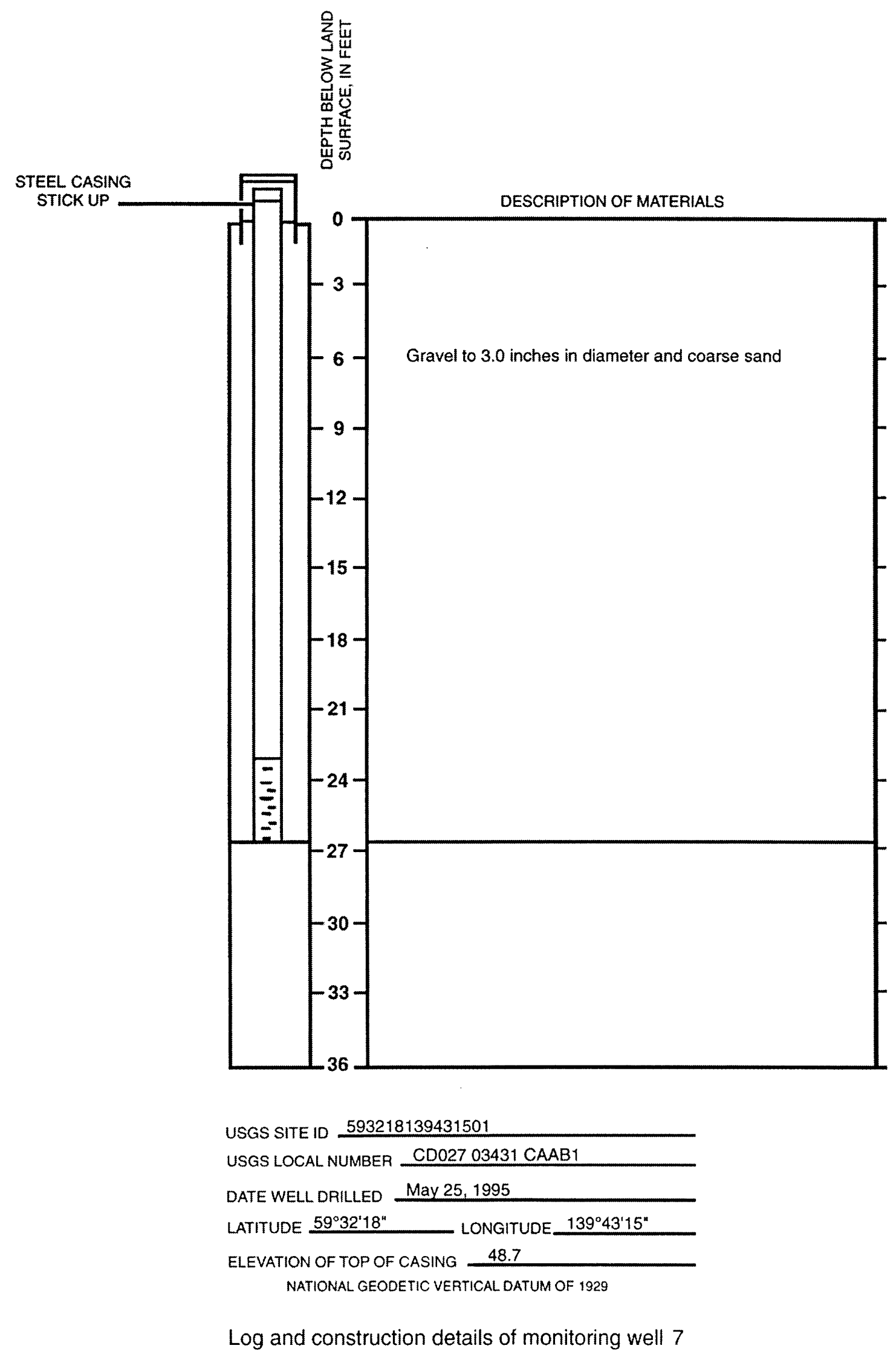




\section{APPENDIX 2}

Water-Level Measurements of Monitoring Wells 1-7, October 1996 to March 1997 

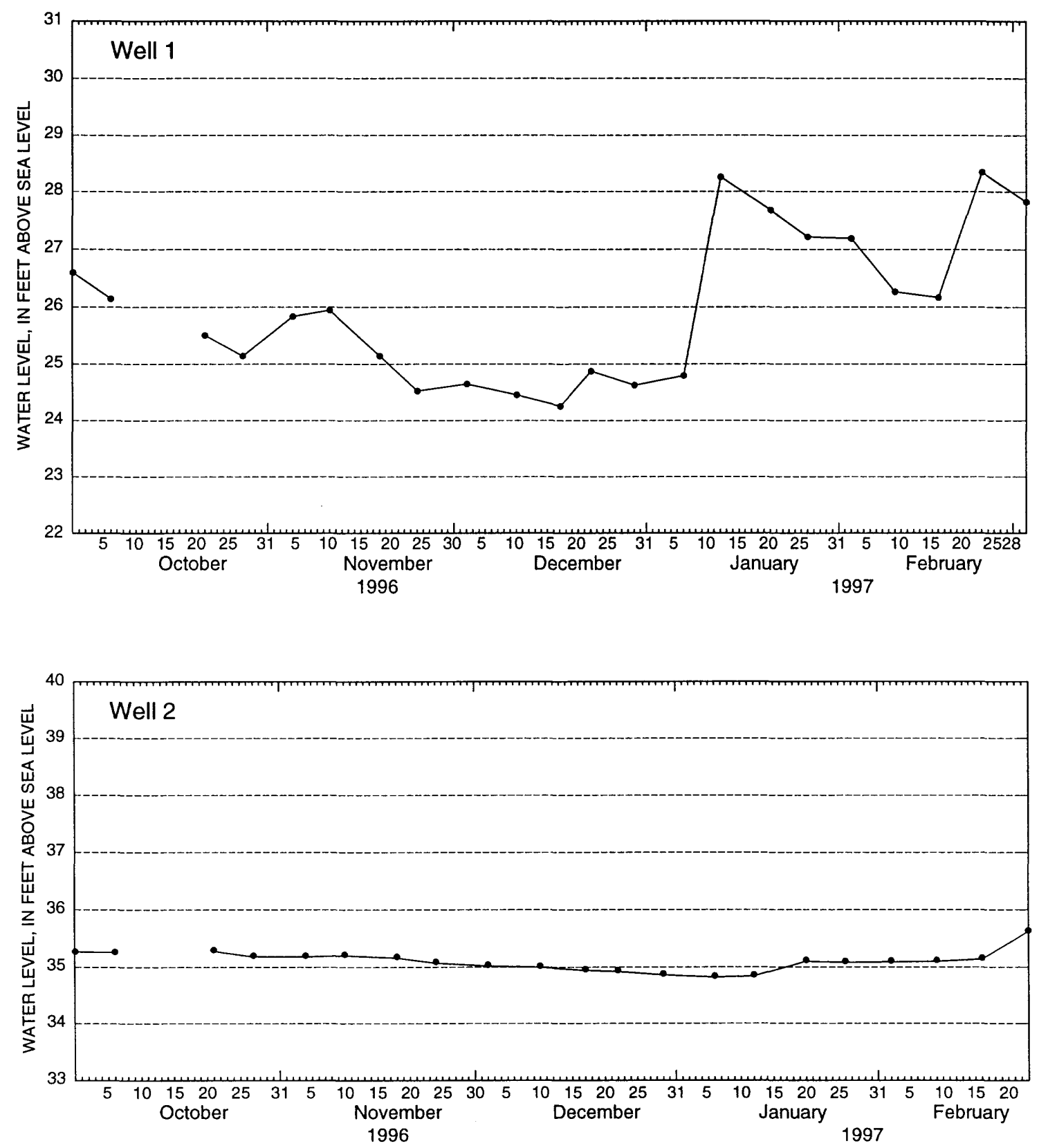

30 Hydrologic Investigation of the Ophir Creek Watershed Near Yakutat, Alaska 

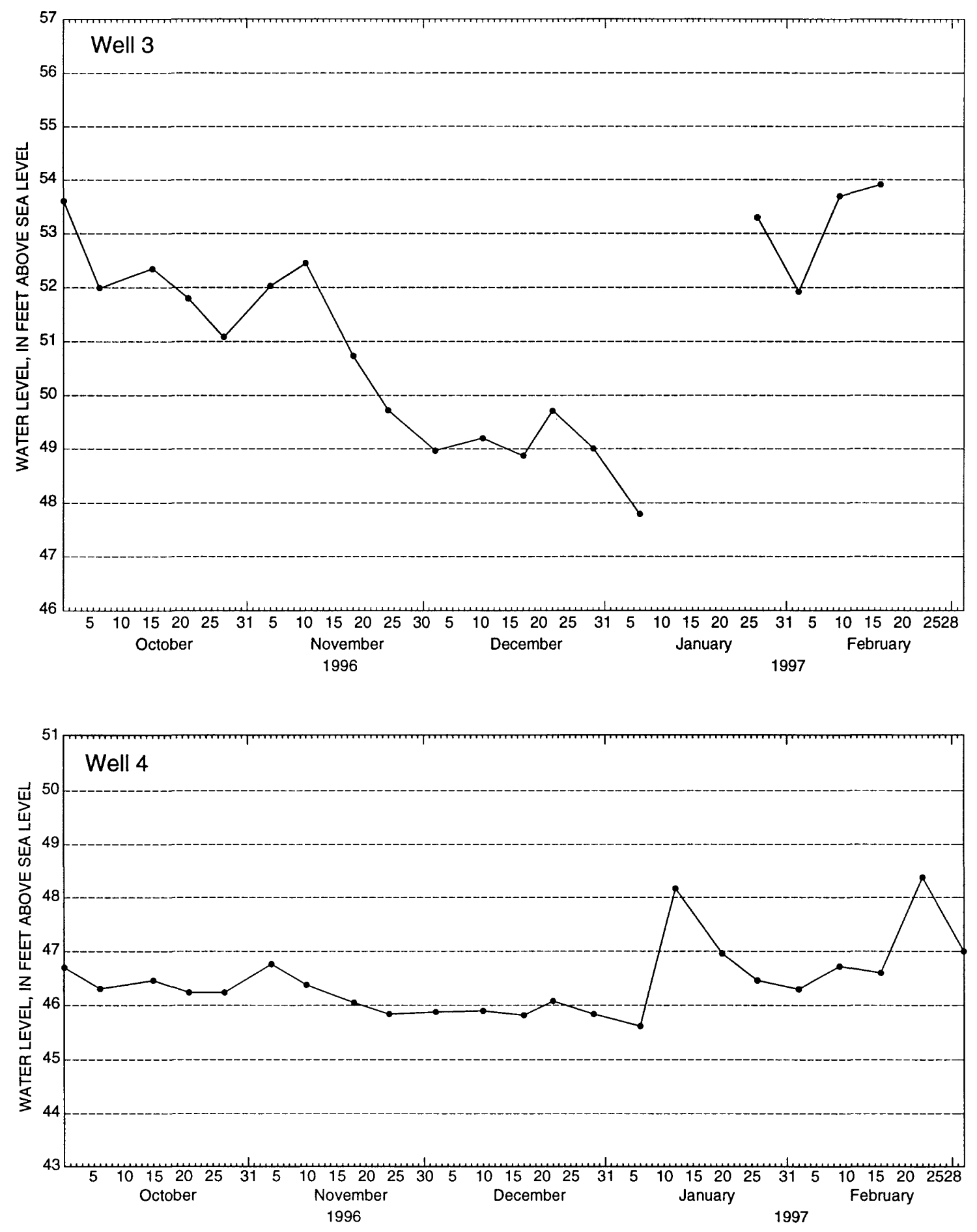